Personal Insolvency Law After the Enterprise Act: An Appraisal

\title{
Adrian Walters
}

Address for correspondence:

Adrian Walters

Academic Legal Studies

Nottingham Law School

Nottingham Trent University

Burton Street

Nottingham

NG1 4BU

Tel: +44-(0)115-8482771

Email: adrian.walters@ntu.ac.uk

(C) Adrian Walters 2004 


\title{
PERSONAL INSOLVENCY LAW AFTER THE
}

\section{ENTERPRISE ACT: AN APPRAISAL}

\begin{abstract}
ADRIAN WALTERS*
This paper offers an appraisal of the recent reforms of personal insolvency law introduced in England and Wales by the Enterprise Act 2002 which came into force on 1 April 2004. The paper suggests that the new law has four key structural elements: (i) the reduction in the duration of bankruptcy, (ii) the lifting of statutory restrictions and disabilities hitherto imposed on undischarged bankrupts, (iii) the new regime of post-discharge restrictions for so-called “culpable” bankrupts, (iv) the introduction of a "fast-track" post-bankruptcy individual voluntary arrangement procedure supervised by the official receiver. The new law is examined in the light of the policies that it seeks to promote and the implications for debtor incentives are considered. The paper's principal conclusions are (i) that the legal incentives for debtors to opt for an individual voluntary arrangement rather than bankruptcy do not appear to be particularly compelling and (ii) that the significant investment required in a system that differentiates between "honest" and "culpable” bankrupts will only be worthwhile if credit providers are prepared to treat the former significantly more favourably than the latter.
\end{abstract}

\section{A. INTRODUCTION}

The provisions in Part 10 of the Enterprise Act 2002 that concern the law of personal insolvency came into force on 1 April 2004. ${ }^{1}$ While much has been said about the

\footnotetext{
* Reader in Law, Nottingham Trent University. An earlier draft of the paper was presented at the annual conference of the Insolvency Lawyers' Association in March 2004. I am grateful to Malcolm Davis-White QC, Desmond Flynn, Donna McKenzie Skene, Riz Mokal, Keith Pond and the JCLS referee for helpful comments. The opinions expressed and any errors are mine alone. All web links given below were active and correct on 1 December 2004.

${ }^{1}$ Enterprise Act 2002, ss 256-269; the Enterprise Act 2002 (Commencement No 4 and Transitional Provisions and Savings) Order 2003 SI 2003/2093 (hereafter "Commencement Order"), art 2(2) and Sch 2. One provision relating to personal insolvency - the requirement introduced by section 262 of the Enterprise Act for the trustee in bankruptcy to obtain the permission of the creditors' committee or the court before bringing legal proceedings under Insolvency Act 1986 (hereafter "IA"), ss 339, 340 or 423 - was brought into force on 15 September 2003: see Commencement Order, art 2(1) and Sch 1.
} 
impact of the Enterprise Act on corporate insolvency, less attention has been given to the Act's reform of the law of personal insolvency. Yet in a society experiencing record levels of personal indebtedness, there is an increasing need to ensure that the available legal responses to individual financial distress are appropriate and fit for purpose. This paper therefore seeks to redress the balance by offering an appraisal of the present bankruptcy system.

In a speech to the British American Chamber of Commerce in New York in October 1998, the then Trade Secretary, Peter Mandelson, gave the first public indication that reform of personal insolvency law was on the agenda:

"We need to examine all our regulatory systems to ensure they do not needlessly deter entrepreneurs such as our bankruptcy laws. Are we sure that they create confidence in enterprise and commerce? I don't think we are confident. I think we need fundamentally to re-assess our attitude in Britain to business failure. Rather than condemning it and discouraging anyone from risking failure, we need to encourage entrepreneurs to take further risks in the future. Here in the United States, I am told that some investors actually prefer to back businessmen and women with one or more failures under their belt because they appreciate the spirit of enterprise shown and recognise the experience that has been gained from it. Can you imagine that in Britain? Rather than sharing the risks with entrepreneurs in this way, most creditors are much more wary of supporting those who have experienced business failure, indeed many of them, including a lot of our high street banks, just run a mile from anyone who taken a leap [sic], taken the risk, failed but wants to try again and those people should be backed."2

According to this vision, the liberalisation of personal insolvency law was one of the steps that Britain would need to take in order to emulate the United States by creating an "enterprise-oriented, risk-taking, failure-tolerant business culture". 3 By 2000, still drawing inspiration from experience in the United States, the substance of the policy that underpins the Enterprise Act reforms had begun to take shape. The key emphasis was on the fostering of enterprise through "responsible risk-taking". The law should encourage honest but responsible entrepreneurs who have pursued a business idea but failed because of the risks inherent in a market economy to "try again". However, "irresponsible" and "culpable" bankrupts should be penalised. This emphasis was reflected in the Insolvency Service's consultation document on the emerging policy,

\footnotetext{
${ }^{2}$ The full text of the speech is at $<$ http://www.dti.gov.uk/ministers/archived/>.

${ }^{3}$ Ibid.
} 
Bankruptcy: A Fresh Start. ${ }^{4}$ The foreword to Fresh Start, written by Stephen Byers, Mandelson's successor as Trade Secretary, gives a flavour of the overall thinking:

\begin{abstract}
"Entrepreneurial activity is a major determinant of growth and is in turn affected by four principal drivers: the perception of opportunities, the capacity of the population, the entrepreneurial infrastructure of the country and attitudes towards creators of businesses. UK cultural attitudes are among the least supportive of entrepreneurs... This is very serious, since a person is only likely to start a business if success brings social recognition and failure does not mean public humiliation. The Government must take a lead in helping to tackle the low level of motivation to start and grow new businesses because motivation correlates directly with entrepreneurial activity. One of the reasons why people in the UK tend to be risk averse is because they see the financial and social costs of failure as outweighing the benefits of success. Bankruptcy law currently makes no distinction (and therefore third parties cannot tell the difference) between those who are honest but unlucky or undercapitalised and the reckless or fraudulent... We believe that a distinction can and should be made between the two groups so that the vast majority of honest bankrupts do not continue to be stigmatised through association with the dishonest."
\end{abstract}

Similar themes were advanced subsequently in a White Paper ${ }^{5}$ and in ministerial statements that accompanied the introduction of the Enterprise Bill into Parliament. ${ }^{6}$

The rhetoric of the "fresh start" for "honest" bankrupts has a strong North American resonance. So, for example, in Local Loan Co v Hunt, the United States Supreme Court pronounced that the principal aim of bankruptcy law was to give "the honest but unfortunate debtor... a new opportunity in life and a clear field for future effort, unhampered by the pressure and discouragement of pre-existing debt.", However, while experience in the United States has exerted a powerful influence on our policy makers, we will see below that the means chosen to distinguish "honest" from "culpable" bankrupts are peculiarly English in design. Moreover, the European context cannot be ignored. The European Commission, through its Enterprise Directorate-General, has conducted its own parallel assessment of the bankruptcy laws of member states ${ }^{8}$ with a view to setting benchmarks for the implementation of policies supportive of enterprise at national level. This process culminated in the

\footnotetext{
${ }^{4}$ Bankruptcy: A Fresh Start - A Consultation on Possible Reform to the Law Relating to Personal Insolvency in England and Wales (2000) (hereafter "Fresh Start").

${ }^{5}$ Productivity and Enterprise: Insolvency - A Second Chance, Cm 5234 (2001) (hereafter "Second Chance").

${ }^{6}$ See Hansard, HC Vol 383, col 49; HL Vol 637, col 142.

${ }^{7} 292$ US 234 at 244 (1934). Even a cursory literature review reveals that the idea of the "fresh start" is deeply embedded within bankruptcy discourse in the United States.

${ }^{8}$ Second Chance, paras 1.7-1.8.
} 
publication of a report, the executive summary of which contains the following statement:

"[L]egal systems can be a real deterrent to a fresh start. Failed entrepreneurs usually learn from their mistakes and can be more successful in the future. The possibility of continuing or starting a new business is affected by both the general consequences of bankruptcy and on the disqualifications and restrictions imposed on those subject to bankruptcy proceedings. At present there is no distinction made between bankrupts who fail through no fault of their own and those who are culpable and little regard is given, in terms of their treatment, to the facts of the individual case. By treating each individual in a proportionate and appropriate manner, nonfraudulent debtors would not be stigmatised through association with fraudulent ones."

The Enterprise Act reforms therefore anticipate wider policy initiatives at the European level that, in line with the goal set by the European Council in Lisbon in 2000, seek to make Europe "the most competitive and dynamic knowledge-based economy in the world" by 2010. ${ }^{10}$ These European initiatives are also premised on the desire to stimulate entrepreneurial activity or, at least, to remove barriers to such activity. Given the tendency of contemporary discourses to portray the economy within the Eurozone as relatively "stagnant" when compared to the "dynamic" economy across the pond, it is not surprising to find that European policy makers have also looked to the United States for inspiration. ${ }^{11}$

In keeping with the policy outlined, the new law has three main structural elements: (i) the reduction in the duration of bankruptcy, (ii) the lifting of statutory restrictions and disabilities hitherto imposed on undischarged bankrupts and (iii) a new regime of post-discharge restrictions designed to deal with what have been termed "irresponsible" or "culpable" bankrupts. Taken in combination, these elements are designed to deliver the "fresh start" policy. A fourth element is the

\footnotetext{
${ }^{9}$ Best Project on Restructuring, Bankruptcy and a Fresh Start: Final Report of the Expert Group (September 2003) (“the Best Project Report”) available at < http://europa.eu.int/comm/enterprise/ entrepreneurship/support_measures/ $>$. The point is reinforced in the Expert Group's recommendation at para 7.3.2. The Best Project Report also cites the Enterprise Act reforms as examples of good practice at para 5.3.2.

${ }^{10}$ Ibid, para 2.1 .

${ }^{11}$ The conclusions of the Best Project Report were based on an earlier study carried out at the instigation of the European Commission entitled Bankruptcy and a fresh start: Stigma on failure and legal consequences of bankruptcy (July 2002), full text at

$<\mathrm{http}$ ://europa.eu.int/comm/enterprise/entrepreneurship/support_measures/failure bankruptcy/bankruptcy.htm>. This study examined attitudes to business failure and the legal consequences of insolvency within the member states and used the United States as its external comparator.
} 
introduction of a "fast-track" voluntary arrangement procedure to be overseen by the official receiver. This seeks to channel debtors who have the means to contribute towards payment of their debts away from bankruptcy and into an approved voluntary arrangement. The attempt to promote individual voluntary arrangements as an alternative to bankruptcy at a time when, in some eyes, the implementation of the "fresh start" policy has made bankruptcy more attractive, is an interesting feature of the overall package. After consideration of the basic structure and functions of personal insolvency law in England and Wales, the paper proceeds to examine the four elements in turn and to draw some tentative conclusions as to their likely cumulative impact. The paper is concerned only with the position in England and Wales. $^{12}$

\section{B. THE STRUCTURE AND FUNCTIONS OF PERSONAL INSOLVENCY LAW}

\section{Bankruptcy}

The law's ultimate formal response to personal insolvency is bankruptcy. Bankruptcy has been described as "a compact to which there are three parties: the debtor, his creditors and society." 13 As between the bankrupt debtor and his creditors, bankruptcy can be seen as a form of statutory composition. The debtor's non-exempt assets $^{14}$ are gathered in, realised and the proceeds distributed among his creditors. The debtor can also be required, to a limited extent, to contribute towards the payment of his debts out of ongoing income. ${ }^{15}$ In return for surrendering his assets (and, possibly, a limited portion of his income), the debtor obtains automatic discharge of

\footnotetext{
${ }^{12}$ The law relating to personal insolvency law is a devolved matter and, accordingly, the reforms have no application in Scotland and Northern Ireland. The Scottish Executive has conducted its own consultation process: see Personal Bankruptcy Reform in Scotland: A Modern Approach (2003) and Modernising Bankruptcy and Diligence in Scotland: Draft Bill and Consultation, full text available at $<\mathrm{http}: / / \mathrm{www}$. scotland.gov.uk/>. On the trajectory of reform in Scotland, see further, D McKenzie Skene, "Morally Bankrupt? Apportioning Blame in Bankruptcy" [2004] Journal of Business Law 171.

${ }^{13}$ Insolvency Law and Practice, Report of the Insolvency Law Review Committee ("Cork Report"), Cmnd 8558 (1982) at para 192.

${ }^{14}$ IA, s 283.

${ }^{15}$ Ibid, s 310 and Section C, infra.
} 
his "bankruptcy debts", meaning the debts or liabilities to which he was subject at the commencement of bankruptcy. ${ }^{16}$

From the standpoint of creditors, bankruptcy is a collection device designed to substitute an orderly collective procedure for a disorderly "race" in which creditors are free on a "first come, first served" basis to pursue their claims individually under ordinary debtor-creditor law and execute them on the debtor's assets. ${ }^{17}$ The standard justification for bankruptcy is that, where the debtor is unable to meet all of his financial obligations, the creditors as a whole are better off in a collective regime than they would be otherwise. This is because the collective regime replaces the race between creditors to pursue their individual claims that, given the debtor's limited means, few are destined to win. ${ }^{18}$ A further point is that bankruptcy prevents creditors who are swifter and stronger from obtaining a disproportionate share of the debtor's assets at the expense of creditors who are slower and weaker and seeks to ensure that everyone gets something whereas, outside bankruptcy, the majority are likely to get nothing. The assets available for distribution may be augmented in a variety of ways. There may be scope for the debtor's trustee in bankruptcy to exercise the statutory avoiding powers. ${ }^{19}$ Also, the trustee in bankruptcy may claim property that is acquired by, or devolves upon, the debtor after the commencement of bankruptcy ${ }^{20}$ and, within limits, surplus from any ongoing income, whether earned or unearned. ${ }^{21}$

From the debtor's standpoint, bankruptcy relieves him of the burden of his debts and offers the prospect of rehabilitation. The debtor obtains relief from harassment by his creditors by virtue of the automatic stay. ${ }^{22}$ Although he must surrender his nonexempt assets, which vest by operation of law in his trustee in bankruptcy, ${ }^{23}$ he is entitled to retain exempt property, such as tools of trade that may enable him to pursue gainful employment, as well as items necessary for meeting his and his

\footnotetext{
${ }^{16}$ Ibid, ss 281, 382.

${ }^{17}$ Where a creditor petitions for bankruptcy under IA, s 264(1)(a), he exercises a class right on behalf of all creditors with the result that the petition can only be withdrawn with the permission of the court: Insolvency Rules 1986 SI 1986/1925 (as subsequently amended) (“IR"), r 6.32.

${ }^{18}$ The seminal reference is T Jackson, The Logic and Limits of Bankruptcy Law (Cambridge, MA, Harvard Press, 1986). For critique and refinement of Jackson's theory see R Mokal, "The Authentic Consent Model" (2001) 21 Legal Studies 400.

${ }^{19}$ See IA, ss 284, 339-344.

${ }^{20}$ Ibid, s 307.

${ }^{21}$ Ibid, s 310.

${ }^{22}$ Ibid, s 285(3). The idea that bankruptcy is a form of debt relief is reflected in the fact that debtors can petition for their own bankruptcy: ibid, s 272 .

${ }^{23}$ Ibid, s 306(1).
} 
family's basic domestic needs. ${ }^{24}$ After a defined period of time, the debtor is automatically discharged from bankruptcy, meaning that he will be released from the obligation to pay his debts. ${ }^{25}$ Discharge does not affect the right of creditors to prove in the bankruptcy and participate in a distribution of the surrendered assets. However, the creditors lose the right to pursue the debtor on the original obligation ${ }^{26}$ and, save to the limited extent allowed by sections 307 and 310 of the Insolvency Act, they cannot look to be repaid out of the debtor's future assets or income. ${ }^{27}$ Thus, by exempting certain property from the bankruptcy estate, by discharging the debtor from his obligations and by preventing the creditors from capturing the debtor's future assets and income for the bankruptcy estate, insolvency law, in theory, gives the debtor scope to resume participation in the credit economy and liberates him to make a productive contribution to society free from the burden of his debts. At the same time, there are certain categories of debt that are not dischargeable for policy reasons. $^{28}$ So, for example, discharge does not release the debtor from any bankruptcy debt incurred through fraud or fraudulent breach of trust and the scope of the discharge in English law is limited accordingly. ${ }^{29}$ Insolvency law therefore seeks to strike a balance between the interest of creditors in recovering what they are owed and the interest of debtors in pursuing their lives productively without a millstone of debt around their necks. ${ }^{30}$ In striking the balance, most legal systems recognise that some form of discharge, whether automatic or court-granted, is necessary. ${ }^{31}$ However, it is clear that the law can be calibrated in a variety of different ways. Thus, under Chapter 7 of the US Bankruptcy Code, which is generally perceived as perhaps the most "pro-debtor" bankruptcy regime in the world, the scope for assets to be kept out of the bankruptcy estate is, broadly speaking, more generous than it is in English

\footnotetext{
${ }^{24} \mathrm{Ibid}$, s 283(2) but note the effect of s 308. Property subject to a restraint order under the Proceeds of Crime Act 2002 is also excluded from the bankrupt's estate: see s 417 of that Act and IA, s 306A.

${ }^{25}$ IA, ss 278-81 and Section C, infra.

${ }^{26}$ Bankruptcy converts rights against the debtor into rights against the debtor's estate: see $R e$ Ravichandran [2004] BPIR 814.

${ }^{27}$ Nor can they claim the benefit of future pension rights. The decision in Re Landau [1998] Ch 223 established that the debtor's contractual rights under a personal pension scheme were "property" within IA, s 436 that formed part of the bankruptcy estate and vested in the trustee in bankruptcy. However, Re Landau was reversed by the Welfare Reform and Pensions Act 1999, s 11 for bankruptcies where the petition was presented after 29 May 2000.

${ }^{28}$ IA, s 281.

${ }^{29} \mathrm{Ibid}, \mathrm{s} 281(3)$. Note also the Higher Education Act 2004 which provides that student loan debts will no longer be released on discharge.

${ }^{30}$ See A Keay, "Balancing Interests in Bankruptcy Law" (2001) 30 Common Law World Review 206.

${ }^{31}$ See J Ziegel, Comparative Consumer Insolvency Regimes - A Canadian Perspective (Oxford and Portland, Oregon, Hart Publishing, 2003).
} 
law, but the scope of the discharge is more limited because there are many more categories of non-dischargeable debts. ${ }^{32}$

While society has an interest in the bankruptcy process as a means of rehabilitating debtors and encouraging them to make a productive contribution, the forgiveness of debtors also has social costs. Firstly, society as a whole must bear the economic cost of individual default. Secondly, the provision of a generous discharge inevitably involves some erosion of social norms of individual responsibility and sanctity of contract that emphasise the moral importance of promise keeping. ${ }^{33}$ As well as requiring the debtor to relinquish his assets, the insolvency law of England and Wales has long exacted a further price for the benefits of bankruptcy relief. All bankrupts face having their affairs investigated by the state through the office of the official receiver, ${ }^{34}$ a process that exposes them to possible prosecution in the event that offences have been committed, to public examination in court and (now) to the possible imposition of post-discharge restrictions. ${ }^{35}$ Historically, the bankrupt debtor has also been made the subject of legal restrictions and disabilities preventing him from participating in certain aspects of public life and from holding certain offices and appointments. ${ }^{36}$ These disciplinary consequences of bankruptcy reflect the view that the debtor's failure to meet his obligations is a matter of public concern that creates risks for the community as a whole and so ought to be investigated and sanctioned. ${ }^{37}$ Bankruptcy law therefore intrudes into the affairs of the debtor in the

\footnotetext{
${ }^{32}$ See US Bankruptcy Code, ss 522-523 and 541. Although bankruptcy law is generally a federal matter in the United States, the individual states retain the power to set exemptions. As a result, some states have extremely generous "homestead" exemptions that allow the family home (or a portion of the equity) to be kept out of the bankruptcy estate: see CJ Tabb, The Law of Bankruptcy (New York, Foundation Press, 1997), ch 9 and MJ White, "Why it Pays to File for Bankruptcy" (1998) 65 University of Chicago Law Review 685.

${ }^{33}$ See further J Kilpi, The Ethics of Bankruptcy (London and New York, Routledge, 1998); T Zywicki, "Bankruptcy as Social Legislation" (2001) 5 Texas Review of Law and Politics 393.

${ }^{34}$ The various official receivers are part of the Insolvency Service, an executive agency of the Department of Trade and Industry: see $<\mathrm{http}: / / \mathrm{www}$.insolvency.gov.uk $>$. However, when an official receiver carries out his statutory functions he does so as an independent office-holder and not as a servant of the Crown: see Re Minotaur Data Systems Ltd [1999] 1 WLR 1129.

${ }^{35}$ Under the Bankruptcy Acts of 1883 and 1914 public examination was compulsory and the debtor could not obtain his discharge until his examination had been concluded. The position now is that a public examination is only held if the official receiver applies for one (usually on grounds of the debtor's failure to co-operate in the investigation into his affairs) or if the creditors force the official receiver's hand: see IA, s 290. The post-discharge restrictions regime is discussed further in Section E, infra.

${ }^{36}$ Cork Report, paras 131-2 and see further Section D.

${ }^{37}$ Cork Report, paras 38, 51-53. This view is exemplified by the Bankruptcy Act 1883 under which the office of the official receiver was first established. The philosophy of the 1883 Act still resonates within the framework and administration of the modern law.
} 
interests of creditors - to ensure that the debtor's assets are identified and surrendered — and in the wider public interest.

A final point, which is of considerable importance given the orientation of the reforms, is that access to the bankruptcy process is not limited to debtors whose debts are wholly or primarily business debts. Consumer debtors - meaning debtors whose debts have been incurred primarily for personal, family or household purposes ${ }^{38}$ are not excluded. Up until the mid-nineteenth century the law distinguished sharply between traders, who were amenable to bankruptcy, and non-traders who were not. ${ }^{39}$ The necessity of credit for business and, accordingly, the necessity for mechanisms to deal with business default were well understood at least from the Industrial Revolution onwards, if not before. ${ }^{40}$ However, the social and cultural acceptance of consumer credit followed much later. For purposes of access to bankruptcy, the trader/non-trader distinction was not abolished until 1861. Within a decade, the powers of the courts to imprison debtors were also radically reduced. ${ }^{41}$ In modern society where economic growth depends to a significant degree on consumer spending which, in turn, is structurally dependent on high levels of consumer credit and personal indebtedness, the provision of legal mechanisms for the relief of consumer debtors is arguably a moral imperative. This is a fortiori given that we live in a society that actively encourages us to consume now and pay later, thereby increasing the scope for default. ${ }^{42}$ Aggregate household debt is not itself a measure of financial distress as in a climate of rising incomes and falling interest rates, individuals can be expected to take on and service greater amounts of debt. However, individuals who are highly leveraged are likely to become overextended should they suffer a sudden loss of income as a result of health problems, redundancy or a change in family circumstances, such as divorce. ${ }^{43}$ Thus, a combination of rising household

\footnotetext{
${ }^{38}$ Borrowing from the definition of "consumer debt" in the US Bankruptcy Code, s 101(8).

${ }^{39}$ For further background, see Cork Report, ch 2, V Markham Lester, Victorian Insolvency: Banrkuptcy, Imprisonment for Debt and Company Winding-Up in Nineteenth Century England (Oxford, Clarendon Press, 1995); R Weisberg, "Commercial Morality, the Merchant Character, and the History of the Voidable Preference" (1986) 39 Stanford Law Review 3.

${ }^{40}$ See Weisberg, supra $\mathrm{n} 39$ for a classic account of the social transformation of the merchant debtor from "social deviant" to "noble and vulnerable statesman... whom the law should protect from the cruel contingencies of economic life".

${ }^{41}$ Debtors Act 1869.

${ }^{42}$ It is perhaps symbolic of the widespread availability of consumer credit that one of the latest entrants into an already crowded market place is a spin-off from the well-known low-cost airline rejoicing in the name "easyMoney": see <http://www.easymoneycreditcard.com>.

${ }^{43}$ For the view (in the American context) that consumer bankruptcies are the product of sudden changes in household circumstances see T Sullivan et al., As We Forgive Our Debtors (New York,
} 
indebtedness, increasing vulnerability to sudden changes in circumstances and the lack of any legal differentiation between business and consumer debtors may go some way to explaining the significant increase in the numbers of consumer bankruptcies that we have experienced in recent times. The government has acknowledged this phenomenon $^{44}$ and, while its enterprise policy is the main driver behind bankruptcy law reform, the current position is that bankruptcy continues to be available to all debtors. $^{45}$ However, it has also acknowledged that alternative solutions, specifically tailored to the problems of consumer debtors, may have to be considered. ${ }^{46}$ Moreover, concerns about lending practices and levels of consumer over-indebtedness are already helping to drive supply-side reform of the consumer credit legislation. ${ }^{47}$ Opinion is divided over whether the use of bankruptcy as a mode of debt relief for consumer debtors should be encouraged. Perhaps unsurprisingly, during the Enterprise Bill's passage, there were some within the lending community who lobbied for a two-tier bankruptcy regime under which consumer debtors would be treated less favourably than business debtors. On the other side of the debate, the National Association of Citizens Advice Bureaux, which favours equal access of consumer debtors to bankruptcy relief, argued that those of its members' clients who have substantial debt problems are effectively denied access to bankruptcy because they cannot afford the court fee and the official receiver's deposit. Accordingly, it recommended a fee exemption for those on low incomes or means-tested benefits. ${ }^{48}$ Beyond reiterating the point that a society that encourages credit is morally beholden to provide mechanisms for dealing with the problems of financial overextension that

Oxford University Press, 1989), The Fragile Middle Class (New Haven and London, Yale University Press, 2000). This view seems to be shared by the UK government: see Hansard, HL Vol 638, col 824.

${ }^{44}$ Second Chance, para 1.46. The government's own figures show that the proportion of bankrupts who had not carried on a business rose from 39\% of all bankrupts in 1992 to $53 \%$ in 2000 .

${ }^{45}$ See Hansard, HC Standing Committee B, 14 May 2002, cols 636-7; HC Vol 387, cols 88-90; HL Vol 638, cols 823-7; H.L. Vol 639, cols 1137-8.

${ }^{46}$ See the White Paper, Fair Clear and Competitive - The Consumer Credit Market in the $21^{\text {st }}$ Century, Cm 6040 (2003), especially ch 5 entitled "Minimising Over-indebtedness". This was perhaps inevitable, given that on the government's own figures, consumer bankruptcies as a proportion of total bankruptcies increased on a rising trend from 39\% in 1992 to 53\% in 2000: see Second Chance, paras 1.45-1.48. There is a widely-held anecdotal view that the Enterprise Act reforms will contribute to an even higher incidence of consumer bankruptcies.

${ }^{47}$ See Fair, Clear and Competitive, supra n 46.

${ }^{48}$ In too deep: CAB clients' experience of debt available at $<\mathrm{http} / / / \mathrm{www}$.citizensadvice.org.uk/>. In $R$ $v$ Lord Chancellor, ex p Lightfoot [2000] QB 597, it was held that the requirement to pay the official receiver's deposit did not infringe a debtor's rights of access to the courts. For proposals designed to address the concerns raised by the CAB see the DCA Consultation Paper, A Choice of Paths, CP 23/04 (2004) available at $<$ http://dca.gov.uk $>$. 
may result, ${ }^{49}$ it is not my purpose to engage in this debate here. The important point for present purposes is that the Enterprise Act reforms are as relevant to consumer debtors as they are to business debtors, notwithstanding the enterprise bias of the underlying policy. I return to the point below in conclusion because it is clearly relevant to any assessment of the likely impact of the reforms.

\section{Individual voluntary arrangements}

The main formal alternative to bankruptcy is the individual voluntary arrangement ("IVA") procedure in Part VIII of the Insolvency Act introduced on the recommendation of the Cork Committee. ${ }^{50}$ A voluntary arrangement is a composition or scheme of arrangement ${ }^{51}$ which arises from a proposal made by a debtor to his creditors. The proposal is formulated in conjunction with an insolvency practitioner or a member of a recognised body ("the nominee") ${ }^{52}$ who is obliged to report to the court on its viability. ${ }^{53}$ The creditors then vote on whether or not to approve the proposal. If it is approved, the nominee becomes the supervisor and oversees its implementation. The key feature of the procedure is that an approved IVA binds dissenting creditors. ${ }^{54}$ However, for the proposal to become binding, it must be approved by a majority of creditors in excess of three-quarters by value. ${ }^{55}$ Ultimately, the success of the IVA depends on the debtor being able to honour its terms. ${ }^{56} \mathrm{~A}$ debtor may propose an IVA as a means of avoiding bankruptcy, or after a bankruptcy order has been made, with a view to having the bankruptcy annulled. ${ }^{57}$ Pending the holding of the creditors' meeting, the court may grant the debtor protection from his creditors in the form of an interim moratorium. ${ }^{58}$ IVAs have proved quite a popular

\footnotetext{
${ }^{49}$ See also Cork Report, para 23.

${ }^{50}$ Ibid, ch 7.

${ }^{51}$ IA, s 253(1).

${ }^{52}$ Ibid, ss 388-89A.

${ }^{53}$ Ibid, s 256(1)(a).

${ }^{54}$ Ibid, s 260.

${ }^{55} \mathrm{IR}, \mathrm{r} 5.23$.

${ }^{56}$ In default, the supervisor or a bound creditor may petition for bankruptcy: IA, ss 264(1)(c), 276.

${ }^{57}$ IA, s 261 (as substituted by Enterprise Act 2002, s 264 and Sch 22). On a debtor's petition where the unsecured bankruptcy debts would be less than the small bankruptcies level (raised from $£ 20,000$ to $£ 40,000$ by the Insolvency Proceedings (Monetary Limits) (Amendment) Order 2004 SI 2004/547) the court has power to adjourn the petition and appoint an insolvency practitioner to consider the possibility of an IVA: IA, ss 273-4.

${ }_{58}$ Ibid, s 252 though, by virtue of s 256A, an IVA may be proposed without the need for an interim order.
} 
alternative to bankruptcy measured in terms of sheer numbers. ${ }^{59}$ As the costs of implementation are generally lower than the costs of administering a debtor's estate in bankruptcy, ${ }^{60}$ creditors have an incentive to approve an IVA on the basis that the projected returns are likely to be higher in the IVA than in bankruptcy. From the debtor's perspective, an IVA involves less publicity than bankruptcy and is a means of avoiding the restrictions and disabilities that apply to undischarged bankrupts. One issue to which I return below is whether, from the debtor's point of view, the Enterprise Act reforms have increased the relative attractiveness of bankruptcy at the expense of the IVA procedure.

\section{County court administration orders}

The county court administration order procedure provides a limited means for dealing with debt problems that is independent of the bankruptcy system. ${ }^{61}$ Under the procedure, the debtor agrees to a payment plan and, in return, is granted protection from his creditors. However, it is only open to judgment debtors whose whole indebtedness is less than the current county court limit of $£ 5,000$. It therefore amounts to a limited income payments regime for small debtors. The Enterprise Act has no impact on the procedure. ${ }^{62}$

\footnotetext{
${ }^{59}$ Between 1997 and 2003 the total of individual insolvencies (bankruptcies and IVAs) per annum in England and Wales has risen from 24,441, of which 4,545 were IVAs (roughly 18\%), to 36,328, of which 8,307 were IVAs (roughly 23\%) (source: Insolvency Service).

${ }^{60}$ If bankruptcy is avoided, the official receiver's fees will not be payable out of the assets. Moreover, the supervision of an IVA usually involves less work than the administration of a bankruptcy estate.

${ }^{61}$ County Courts Act 1984, Part VI. For background, see Cork Report, paras 68-73, 151-65.

${ }^{62}$ The government is now considering possible non-court-based alternatives designed to meet the needs of consumer debtors who have no assets and no significant income: see Fair, Clear and Competitive, supra n 46 at para 5.79 and A Choice of Paths, supra n 48. Another possible model is the debt arrangement scheme introduced in Scotland by the Debt Arrangement and Attachment (Scotland) Act 2002 on which see D McKenzie Skene, "Dealing with Multiple Debt" [2002] Insolvency Lawyer 212 and "The Debt Arrangement Scheme" (2003) 39 Scots Law Times 289.
} 


\section{THE IMPACT OF THE ENTERPRISE ACT ON THE BANKRUPT'S CREDITORS: DISCHARGE AND OTHER MATTERS}

\section{Reduction in the duration of bankruptcy}

From 1 April 2004, section 279 of the Insolvency Act 1986 (as substituted by section 256 of the Enterprise Act 2002) provides that in all cases discharge from bankruptcy will normally occur automatically at the end of the one-year period beginning with the date on which the bankruptcy commenced. Moreover, if before the end of the oneyear period the official receiver files a notice in court stating that investigation of the conduct and affairs of the bankrupt under section 289 of the Insolvency Act is unnecessary or concluded, the bankrupt will be discharged on the date the notice is filed. ${ }^{63}$ Subject to what is said below about the court's limited power to suspend discharge, it follows that debtors will generally be entitled to discharge no later than one year after the date of the bankruptcy order, a reduction from the previous periods of three years and two years in the case of summary administration. ${ }^{64}$ This marks the latest stage in the evolution of a process started by the Insolvency Act $1976 .{ }^{65}$

A person who was an undischarged bankrupt immediately before 1 April 2004 ("a pre-commencement bankrupt") is subject to the transitional provisions set out in section 256(2) and Schedule 19 of the Enterprise Act. The general principle is that a pre-commencement bankrupt will be discharged from bankruptcy at whichever is the earlier of: (i) the end of the one-year period beginning on 1 April 2004 or (ii) the end of the relevant period applicable to the bankrupt under section 279(1)(b) of the Insolvency Act as it had effect immediately before 1 April 2004. So, for example, an individual made bankrupt on 31 March 2004 will fall within (i) and be entitled to his discharge on 1 April 2005 whereas an individual made bankrupt on 1 September 2001 will fall within (ii) and be entitled to his discharge on 1 September 2004. Anyone whose bankruptcy commenced after 1 April 2002 (or after 1 April 2003 in the case of

\footnotetext{
${ }^{63}$ IA, s 279(2); IR, r 6.214A. Creditors must be notified and they have a right to object.

${ }^{64} \mathrm{~A}$ certificate of summary administration could formerly be issued where the aggregate of the unsecured bankruptcy debts was less than the small bankruptcies level (formerly $£ 20,000$ ). The relevant provision (IA, s 275) was repealed from 1 April 2004.

${ }^{65}$ For background see Cork Report, paras 136-40. Before 1976, discharge could only be granted by the court.
} 
a summary administration) will therefore benefit from an earlier discharge. ${ }^{66}$ Moreover, so long as such pre-commencement bankrupts continue to co-operate with the official receiver or their trustee in bankruptcy between 1 April 2004 and the discharge date, they have no exposure under the post-discharge restrictions regime. ${ }^{67}$

Considered in isolation the change has no impact on the formal structure of bankruptcy law. The debtor's non-exempt assets, including after-acquired assets, must still be surrendered. The reduction in the period between adjudication and discharge does not directly affect the scope of the provisions on exempt property ${ }^{68}$ and non-dischargeable debts. ${ }^{69}$ The debtor remains under continuing obligations to provide the official receiver and his trustee in bankruptcy with information about his affairs (such as information that may assist in the identification of assets that form part of the estate) both before and after discharge. ${ }^{70}$ Likewise the trustee remains under a duty to carry out his remaining functions in relation to the estate until such time as he obtains his release under section 299 of the Insolvency Act. In these respects, the creditors are getting the same deal. As the bankruptcy debts will be discharged at some point, it may not much matter from the creditors' perspective when they are discharged, be that after one year or some longer period. ${ }^{71}$ However, the practical significance of the change lies in the time constraints that it imposes on the official receiver and the trustee with regard to the scope and administration of the bankruptcy. The official receiver will be under pressure to complete his investigations and, if necessary, procure the issue of proceedings for a bankruptcy restrictions order ${ }^{72}$ within the one-year period. Similarly, the trustee must bring any application for an income payments order ${ }^{73}$ before discharge. A further point is that after-acquired property can only be captured for the estate to the extent that it is

\footnotetext{
${ }^{66}$ Under the transitional provisions, there is an exception if a certificate of summary administration is revoked on or before 1 April 2004: see Commencement Order, art 8. Also, any existing order suspending a pre-commencement bankrupt's discharge will continue in effect by virtue of Enterprise Act 2002, Sch 19, para 4(2).

${ }^{67}$ Ibid, art 7 and Section E, infra.

${ }^{68}$ IA, s 283.

${ }^{69}$ Ibid, s 281.

${ }^{70}$ Ibid, ss 291(4), (5); 333(1), (3).

${ }^{71}$ See Fresh Start, para 7.2. This ignores the point that bankruptcy may have a salutary effect as regards reacquisition of credit: see the Finance and Leasing Association's response to Fresh Start (suggesting that lenders may be less sympathetic to former bankrupts in a system which discharges them after six months than in a system which discharges them after, say, three years) at $<$ http://www.fla.org.uk/fla_home/Consultation_Papers/bankruptcy.doc $>$.

${ }^{72}$ Section E, infra. Note, however, that a prosecution for a bankruptcy offence in Part IX, Chapter VI of the Insolvency Act can be commenced after discharge: IA, s 350(3).

${ }^{73}$ Section C4, infra.
} 
acquired by, or devolves upon, the bankrupt before discharge. It was concern about the time needed to carry out a proper investigation of debtors' financial circumstances that prompted the government to shelve its original proposal to reduce the duration of bankruptcy to six months. ${ }^{74}$

One striking feature of the overall reform package is that, while a regime designed to distinguish between honest and culpable bankrupts is now in place, ${ }^{75}$ the availability of the automatic discharge does not, as a general rule, depend on the debtor's conduct. All debtors, regardless of whether or not they are made the subject of a bankruptcy restrictions order, are entitled to be discharged after one year. The post-discharge restrictions regime is concerned only to protect the public in the future from those who have engaged in misconduct. Misconduct that would give grounds for a bankruptcy restrictions order does not under the law as it stands give grounds for discharge to be refused absolutely. ${ }^{76}$ The court does have a limited power under section 279(3) of the Insolvency Act to suspend discharge on the application of the official receiver or the trustee ${ }^{77}$ until the end of a specified period, or the fulfilment of a specified condition. However, the court can only exercise this power if satisfied that the bankrupt has failed or is failing to comply with his obligations to the official receiver and/or his trustee. ${ }^{78}$ It therefore provides a limited mechanism that is used in practice to compel the debtor to co-operate with those who are administering his affairs for the benefit of the bankruptcy estate. It cannot be used to deny discharge absolutely. ${ }^{79}$ In one sense, nothing has changed. Under the old law, debtors were entitled to automatic discharge after three years (or two years in the case of summary administration) regardless of their conduct, subject only to the court's power to

\footnotetext{
${ }^{74}$ Fresh Start, para 7.4 and see also the Finance and Leasing Association's consultation response, supra $\mathrm{n} 71$. of misconduct that will ground denial of discharge in a Chapter 7 case: see Tabb, supra n 32, 701-11.

${ }^{77}$ Under the previous law, only the official receiver could apply. As a consequence, if the occasion arose, the trustee in bankruptcy needed to give sufficient notice to enable the official receiver to make the application before the debtor was automatically discharged. For an illustration of the problems that arose in practice see: Bagnall v Official Receiver [2003] EWHC 1398 (Ch), [2003] 3 All ER 613 affirmed [2003] EWCA Civ 1925.

${ }^{78}$ IA, s 279(4); IR, r 6.215. For the bankrupt's principal obligations see IA, ss 272(2), 288 (duty to submit a statement of affairs), 291 (duty to deliver up assets, books, papers and records to the official receiver), 312, 333 (duty to provide information and assistance to the trustee).

${ }^{79}$ For examples of circumstances in which the power may be exercised see Holmes $v$ Official Receiver [1996] BCC 246; Hardy v Focus Insurance Co Ltd [1997] BPIR 77; Jacobs v Official Receiver [1999] 1 WLR 619; Thorogood v Official Receiver [2003] EWHC 1971 (Ch); Bagnall v Official Receiver, supra n 77.
} 
suspend discharge in the manner just described. This prompted the criticism that bankruptcy law did not sufficiently differentiate between honest and culpable bankrupts. ${ }^{80}$ The post-discharge restrictions regime is designed to meet this criticism. However, it must be emphasised that the differentiation is achieved through the imposition of restrictions and disabilities on culpable bankrupts. There is no general power to deny discharge, even where the debtor's conduct has been particularly egregious.

\section{2. “Repeat” bankrupts}

Under the old law, an individual who had been an undischarged bankrupt at any time in the period of 15 years ending with the most recent bankruptcy order could only be discharged by the court under section 280 of the Insolvency Act and the application for discharge could not be made until five years had elapsed from the date of such order. However, a "repeat" bankrupt whose most recent bankruptcy commenced on or after 1 April 2004 is no longer subject to the old law and will be entitled to a further automatic discharge one year after the order. ${ }^{81}$ Structurally, this is a significant extension of the "fresh start" policy because it treats a second-time or even a serial bankrupt in exactly the same way as a first-time bankrupt. All are entitled to the discharge; all are exposed to a bankruptcy restrictions order should their conduct merit it. The mere fact of "repeat" bankruptcy is neither a ground for denying discharge nor a ground for a bankruptcy restrictions order. At the level of policy, this reflects the acceptance that the honest entrepreneur may legitimately fail more than once and is consistent with the attempt to foster progressive attitudes towards such failure. Even so, the position in relation to "repeat" bankrupts is now prima facie more liberal than the corresponding position in the United States where, under the Bankruptcy Code, the receipt of a discharge within six years of a subsequent filing is a ground for denial of discharge. ${ }^{82}$ The principal sanction available to combat serial

\footnotetext{
${ }^{80}$ Fresh Start, paras 6.1-6.4.

${ }^{81}$ Compare the former section 279(1)(a) and the present section 279(6). For transitional provisions, see Enterprise Act 2002, Sch 19, para 5. A "repeat" bankrupt whose most recent bankruptcy commenced before 1 April 2004 will be discharged (i) at the end of the five-year period beginning on 1 April 2004 or (ii) at such earlier time as the court may order on an application under Insolvency Act 1986, s 280 heard after 1 April 2004.

${ }^{82}$ See US Bankruptcy Code, s 727(8), (9) and Tabb, supra n 32, 709-11.
} 
abuse of bankruptcy in England and Wales is the post-discharge restrictions regime discussed in Section E.

\section{The bankrupt's home}

Section 261 of the Enterprise Act inserts two new sections into the Insolvency Act which restrict the ability of a trustee in bankruptcy to realise the bankrupt's interest in a dwelling-house. Section 283A of the Insolvency Act applies in relation to the bankrupt's interest in a dwelling-house which at the date of the bankruptcy was the sole or principal residence of the bankrupt, the bankrupt's spouse or former spouse. It is clear that such an interest forms part of the bankrupt's estate and vests in his trustee in bankruptcy for the benefit of his creditors. ${ }^{83}$ We have seen that bankruptcy discharge does not affect the administration of the bankruptcy estate, which may continue for many years. Assets in the estate can therefore be realised either before or after the debtor is discharged. Under the old law, it was open to the trustee to speculate in a rising market and delay realising the debtor's interest in his home to take advantage of any subsequent price rise. Given the recent housing market boom, this proved to be an attractive strategy. However, it meant that the former bankrupt and his family often faced the prospect of having to wait years for the position to be resolved. On the premise that this state of affairs was inequitable, ${ }^{84}$ section $283 \mathrm{~A}$ provides that the trustee must take steps to deal with the bankrupt's interest in the manner set out in section $283 \mathrm{~A}(3)$ within three years beginning with the date of bankruptcy or else the interest will cease to be comprised in the estate and will re-vest in the bankrupt. ${ }^{85}$ If the bankrupt does not inform the trustee or official receiver of the interest within the first three months of the bankruptcy then the three years will only start to run from the date on which either of them becomes aware of it. ${ }^{86}$ The requirement on the trustee to "use it or lose it" benefits bankrupts in the sense that

\footnotetext{
${ }^{83}$ IA, ss $283,306,436$.

${ }^{84}$ See Re Byford (deceased) [2003] EWHC $1267(\mathrm{Ch})$, para [15]. The issue was not raised in either Fresh Start or Second Chance. It was flagged up first by the Insolvency Practices Council and then by the Association of Business Recovery Professionals (R3) in its response to Second Chance.

${ }^{85}$ For consequential administrative provisions dealing with re-vesting see IR, rr 6.237A-B.

${ }^{86} \mathrm{IA}, \mathrm{s} 283 \mathrm{~A}(5)$. The court has power to substitute a longer period than three years and there are various rule-making powers that give scope for the three-year period to be reduced or the provision to be disapplied altogether: IA, s 283A(6)-(9); IR, r 237C. It is also open to the trustee in bankruptcy to surrender his interest to the bankrupt where the continued vesting of the property in the estate is of no benefit to creditors or its re-vesting will facilitate a more efficient administration: IR, r 6.237CA.
} 
they and their families will at least know where they stand within a reasonable period of time in relation to what may often be the main asset in the bankruptcy. Precommencement bankrupts also benefit under the transitional provisions in section 261(7)-(10) of the Enterprise Act. The effect of these provisions is that the trustee of the estate of any pre-commencement bankrupt that is still under administration will need to take steps to realise the bankrupt's interest in a dwelling-house caught by section $283 \mathrm{~A}(1)$ within three years from 1 April $2004 .^{87}$

The second provision is section 313A of the Insolvency Act. This has the same scope as section $283 \mathrm{~A}(1)$ in that it applies where property comprised in the estate consists of an interest in a dwelling-house which at the date of the bankruptcy was the sole or principal residence of the bankrupt, the bankrupt's spouse or former spouse. Under section 313A, if the value of the bankrupt's interest is below the prescribed level, ${ }^{88}$ the court is obliged to dismiss any application by the trustee for an order for sale or possession or for a charging order under section 313. Again, this is a prodebtor measure designed to protect debtors with low-value interests from having their home and family lives disrupted when, at best, the benefit to creditors may be marginal given that the costs of realisation are likely to absorb a considerable part of the proceeds. It should be noted that section $283 \mathrm{~A}$ and $313 \mathrm{~A}$ are an addition to the existing provisions in sections 335A-337 which, to a limited extent, protect the occupation rights of the bankrupt and his family.

\section{Income payment orders}

A bankrupt's income does not automatically vest in his trustee in bankruptcy. However, section 310 of the Insolvency Act provides a mechanism - the income payments order ("IPO") — whereby surplus income over and above that necessary to meet the reasonable domestic needs of the debtor and his family can be captured for the estate. ${ }^{89}$ The underlying policy is that those who have sufficient income should be required for a finite period of time to make some contribution towards payment of

\footnotetext{
${ }^{87}$ For the practical implications see S Frieze, "The Principal Residence — 'Use it or Lose it"” (2004) 17 Insolvency Intelligence 106.

${ }^{88} £ 1,000$ (after deduction of mortgage debt, any other third party interest and the reasonable costs of sale): see the Insolvency Proceedings (Monetary Limits) (Amendment) Order 2004 SI 2004/547.

${ }^{89}$ For further background see Cork Report, paras 591-8 and G Miller, "Income Payments Orders" (2002) 18(2) Insolvency Law \& Practice 43.
} 
their bankruptcy debts for the benefit of creditors. The government has emphasised that nothing in the overall reform package is intended to detract from this "can pay, should pay" policy. ${ }^{90}$ To further this aspect of policy, the Enterprise Act makes two refinements to the existing system. Firstly, section 259 of the Enterprise Act amends section 310(6) to provide that an IPO can continue in effect beyond discharge but may not end after the period of three years beginning with the date on which it was made. Under the previous law, the general rule was that IPOs should not have effect after discharge and, although by virtue of the former section $310(6)(b)$, the court could provide for the order to continue in force after discharge (but for no longer than three years after the making of the order), it was almost universal practice for the courts to provide for the order to cease to have effect on discharge. The amendment is therefore designed to encourage the court to make full use of the jurisdiction for the benefit of creditors while, through retention of the three-year time limit, striking a balance between the interests of creditors and debtor rehabilitation. Secondly, section 260 of the Enterprise Act inserts a new section 310A into the Insolvency Act which provides that the debtor and his trustee (or, where appropriate, the official receiver) can enter into a binding income payments agreement ("IPA") without the need for a court order under section 310. Like IPOs, IPAs are capable of running beyond discharge for up to a maximum of three years from the date of the agreement and they can be enforced in exactly the same way. ${ }^{91}$ By removing the necessity for a court order, section $310 \mathrm{~A}$ is designed to reduce costs and produce better returns for creditors. As the available evidence suggests that the majority of IPOs are obtained with the consent of the debtor, ${ }^{92}$ the provision of an out-of-court means to achieve the same result is sensible. Indeed, the creation of an administrative system alongside the court-based IPO system reflects a general legislative trend in favour of parallel courtbased and out-of-court schemes that offer the possibility of a cost-effective outcome while providing the fall-back of a formal court route should the parties fail to agree. In the present context, the original model was the disqualification undertakings regime. ${ }^{93}$ The post-discharge restrictions regime is also designed in this way. ${ }^{94}$

\footnotetext{
${ }^{90}$ See Fresh Start, para 7.6; Second Chance, paras 1.9, 1.20

${ }^{91} \mathrm{IA}, \mathrm{s} 310 \mathrm{~A}(2),(5)$. The terms of an IPA can be varied by the parties or the court: s 310A(6)-(7).

${ }^{92}$ Fresh Start, para 7.7.

${ }^{93}$ Company Directors' Disqualification Act 1986, ss 1A, 7(2A), 8(2A); A Walters, "Bare Undertakings in Directors' Disqualification Proceedings" (2001) 22 Company Lawyer 290.

${ }^{94}$ Section E, infra.
} 


\section{Summary}

The basic structure of bankruptcy law, at least as it affects the debtor and his creditors, has not changed. All debtors are entitled to a discharge (in one year rather than two or three years) but in return they must surrender their non-exempt assets. For debtors with significant assets as well as income, bankruptcy should still be considered a last resort. However, for debtors with no or few assets, the reduction in the discharge period is likely to increase the attractiveness and incidence of bankruptcy at the expense of the IVA procedure. Even though there is a clear expectation through the IPO/IPA regime that the debtor's income should be captured, one possible model of bankruptcy that emerges in a "no assets" case is a three-year payment plan (under an IPA) coupled with a generous discharge. From the debtor's standpoint, this is prima facie more attractive than, say, an IVA for a period in excess of three years that requires the debtor to contribute from income for the entire duration of the arrangement and, at the creditors' insistence, contains other provisions, such as a provision capturing property acquired by the debtor during the course of the arrangement, ${ }^{95}$ when such property can only be captured in bankruptcy during the one-year period. In terms of debtor incentives, much will depend in these cases on (i) whether the remaining disciplinary effects of bankruptcy, including the debtor's potential exposure under the post-discharge restrictions regime, provide an equally powerful disincentive and/or (ii) whether creditors adjust their demands as to the duration and terms of IVAs ${ }^{96}$ and/or (iii) whether IVAs offer the prospect of genuine rehabilitation in the sense of attracting a better credit-rating than bankruptcy. ${ }^{97}$ In addition, the reforms place greater pressure on the official receiver and on trustees in bankruptcy to pursue their investigations quickly. IPAs will need to be considered early on to allow sufficient time for an application for an IPO to be made in the event that agreement cannot be reached. ${ }^{98}$ Action in respect of the bankrupt's home will

\footnotetext{
${ }^{95}$ See R3's Standard Conditions for Individual Voluntary Arrangements, cl 28.

${ }^{96}$ In a sample of IVAs studied by Keith Pond, over 70\% were five years in length: see K Pond, "New Rules and New Roles for the Individual Voluntary Arrangement" (2002) 18(1) Insolvency Law \& Practice 9.

${ }^{97}$ Pond, supra n 96 suggests that IVAs and bankruptcies are equally weighted at least for credit reference purposes. The structural relationship between IVAs and bankruptcies is considered further in Section F, infra.

${ }^{98}$ If the debtor has provided all the relevant information, his refusal to sign up to an IPA will not of itself ground an application to suspend discharge.
} 
also have to be taken quickly given the effect of the new section 283A. This pressure will be $a$ fortiori if the numbers of bankruptcies continue to increase. ${ }^{99}$

\title{
D. REDUCING THE STIGMA OF BANKRUPTCY FOR HONEST AND UNFORTUNATE DEBTORS
}

A key aspect of the policy underlying the reforms is that steps should be taken to reduce the stigma of bankruptcy for honest and unfortunate debtors. We saw in Section $\mathrm{B}$ that the imposition of restrictions and disabilities on undischarged bankrupts has traditionally been motivated by the view that the debtor's failure to meet his obligations is a matter of public concern. The implication of this view is that the law should stigmatise the undischarged bankrupt as someone who inherently cannot be trusted in order to protect the public in the future. As the Cork Report put it:

\begin{abstract}
"A bankrupt should not only be subject to restrictions as respects the circumstances in which he can freely obtain further credit, but he should, by virtue of the gravity of his conduct giving rise to the bankruptcy, be disqualified from holding certain positions, particularly those of a public nature involving trust and confidence, and where a record of integrity and competence is sought. ${ }^{, 100}$
\end{abstract}

Thus, as the law stood before 1 April 2004, an undischarged bankrupt was automatically banned, on pain of criminal sanction, from obtaining credit of $£ 250$ or more without disclosing his status ${ }^{101}$ and from acting in any of the following capacities: $^{102}$ company director, ${ }^{103}$ insolvency practitioner, ${ }^{104}$ member of parliament, ${ }^{105}$ chairman of a land tribunal, ${ }^{106}$ school governor, ${ }^{107}$ member of a

\footnotetext{
${ }^{99}$ In the final quarter of 2003, there were 10,271 individual insolvencies (meaning bankruptcy orders and IVAs) in England and Wales (source: DTI), the highest level for 11 years and the second-highest since records began in 1960. The trend in 2004 continued upwards. The figures for the first three quarters were 10,294, 11,214, 11,967 (source: DTI).

${ }^{100}$ Para 1839.

${ }^{101}$ IA, s 360(1)(a).

${ }^{102}$ The list is illustrative not exhaustive.

${ }^{103}$ Company Directors' Disqualification Act 1986, s 11.

${ }^{104}$ IA, ss 390(4)(a), 389.

${ }^{105}$ Ibid, s 427.

${ }^{106}$ Agriculture Act 1947, Sch 9, para 13(4).

${ }^{107}$ Education (School Government) Regulations 1989 SI 1989/1503, reg 6(1).
} 
regional or local flood defence committee, ${ }^{108}$ member of an internal drainage board, ${ }^{109}$ estate agent, ${ }^{110}$ practising solicitor, ${ }^{111}$ charity trustee, ${ }^{112}$ pension trustee, ${ }^{113}$ member of a local authority ${ }^{114}$ and justice of the peace. ${ }^{115}$ During the consultation process that preceded the introduction of the Enterprise Bill into parliament, the government questioned the premise that a bankrupt is automatically to be regarded as a social menace essentially on the basis that insolvency is a multi-causal phenomenon. Not all bankruptcies result from the debtor's misconduct or irresponsibility:

\footnotetext{
"The argument that, by becoming bankrupt, an individual businessperson must at the very least have shown poor judgment, takes no account of the risks that are an everyday part of business life and which have to be managed as well as possible. It is the nature of risk-taking that, on occasions, there is bound to be failure. For a society to be genuinely enterprising the cost of failure (and therefore the fear of failure) must not be too high."116
}

It therefore promoted the view that the failure of honest and unfortunate businesspersons is a socially acceptable consequence of a market economy that should not be stigmatised, given that stigma may actively discourage such persons from participating in the economy in the future and so undermine the "fresh start". 117 Hence, it was proposed that bankruptcy per se should be derestricted and a postdischarge restriction regime introduced to differentiate the culpable from the honest, so as to stigmatise the former only.

In line with the derestriction policy, the Enterprise Act made the following changes. Firstly, from 1 April 2004, the prohibitions on an undischarged bankrupt being or becoming a member of parliament or a member of a local authority were lifted by sections 266-7 of the Enterprise Act and replaced by similar prohibitions extending only to bankrupts or former bankrupts who are subject to post-discharge

\footnotetext{
${ }^{108}$ Environment Act 1995, Sch 5, para 3.

${ }^{109}$ Land Drainage Act 1991, Sch 1, Pt 3, para 9.

${ }^{110}$ Estate Agents Act 1979, s 23.

111 Solicitors Act 1974, s 15.

112 Charities Act 1993, ss 72(1)(b), (3) and (4).

${ }_{113}$ Pensions Act 1995, ss 29(1)(b) and (5)(a).

${ }^{114}$ Local Government Act 1972, s 80.

115 Justices of the Peace Act 1997, s 65.

${ }^{116}$ Fresh Start, para 9.2. See also Second Chance, para 1.21.

117 The European Commission takes a similar position: see the Best Project Report, para 5.3.2.
} 
restrictions. ${ }^{118}$ Secondly, also from 1 April 2004, the prohibition on an undischarged bankrupt being or becoming a justice of the peace was repealed by section 265 of the Enterprise Act 2002. ${ }^{119}$ From the same date, the Secretary of State for Trade and Industry has power under section 268 of the Enterprise Act to make an order repealing or revoking a "disqualification provision", meaning a provision which disqualifies a bankrupt from (i) being elected or appointed to an office or position, (ii) holding an office or position, or (iii) becoming or remaining a member of a body or group. This enables the Secretary of State to keep under review "the relevance of restrictions that appear unnecessary or outdated"120 and to lift restrictions on undischarged bankrupts without the need for primary legislation where she considers it appropriate to do so. It is anticipated that orders under the section will generally follow the pattern of sections 266-7 of the Enterprise Act in respect of membership of parliament and local authorities. In other words, current prohibitions on undischarged bankrupts are likely to be replaced over time with equivalent prohibitions on bankrupts or former bankrupts who are subject to post-discharge restrictions so as to reflect the overall policy that bankruptcy per se should not be stigmatised in the absence of proven misconduct. There is clear scope in section 268(5) of the Enterprise Act for the Secretary of State's order-making power to be exercised in this way. The core prohibitions in the insolvency legislation on undischarged bankrupts obtaining credit without disclosure of status and acting as company directors or insolvency practitioners remain intact. ${ }^{121}$ Furthermore, the derestriction provisions of the Enterprise Act have no direct impact on professional bodies and regulators whose rules may prevent undischarged bankrupts from entering or continuing in a particular profession or occupation. Indeed, the impact of bankruptcy on members of professional bodies remains a powerful reason for them to avoid it and pursue IVAs as an alternative. For others, the derestriction policy may tend to reinforce the relative

\footnotetext{
${ }^{118}$ For members of parliament, see IA, s 426A. The original prohibition continues to apply to individuals made bankrupt in Northern Ireland and Scotland: IA, s 427, as amended by the Enterprise Act 2002, s. 266(2).

${ }^{119}$ For the rationale behind the lifting of this restriction see Hansard, HC Standing Committee B, 14 May 2002 at cols 675-6. The repealed provision is not replaced by a similar prohibition on those who are subject to post-discharge restrictions. This is presumably because the Lord Chancellor has a general power to appoint and remove JPs as appropriate.

${ }^{120}$ Second Chance, para 1.24 .

${ }^{121}$ Despite the derestriction policy, legislation continues to be enacted that imposes fresh restrictions on undischarged bankrupts: see Company Directors' Disqualification Act 1986, ss 22C and 11, automatically disqualifying an undischarged bankrupt from acting as a director of an NHS foundation trust without permission of the court.
} 
attractiveness of bankruptcy, unless they happen to have some pressing need to avoid any of the remaining restrictions (in particular, the ban on acting as a company director without permission of the court imposed by section 11(1) of the Company Directors' Disqualification Act).

As regards the disciplinary effects of bankruptcy, one other change should be mentioned. Section 289 of the Insolvency Act (as substituted by section 258 of the Enterprise Act) obliges the official receiver to investigate the conduct and affairs of each bankrupt (including his conduct and affairs before the making of the bankruptcy order), and make such report (if any) to the court as he thinks fit. This reflects the former provision. However, section 289(2) now also provides that the obligation to investigate does not apply to a case in which the official receiver thinks an investigation is unnecessary. This subsection gave rise to concern during the Enterprise Bill's passage, the main objection being that it would lead to reduced scrutiny and make bankruptcy an "easier ride", particularly for consumer debtors. ${ }^{122}$ However, it appears that section 289(2) is a product of the abolition of summary administration rather than a significant change of substance. Under the former section 289(5), the official receiver was only obliged to carry out an investigation in a summary case ${ }^{123}$ if he thought fit. Section 289(2) therefore preserves a limited discretion that is only likely to be exercised in the context of small bankruptcies. In practice, it is anticipated that all bankrupts will still have to go through the official receiver's standard vetting procedures which are designed (i) to establish whether or not a case should be investigated further with a view to possible prosecution or action under the post-discharge restrictions regime and (ii) to secure and protect the assets with a view to determining whether a creditors' meeting should be called and a private sector insolvency practitioner appointed as trustee. ${ }^{124}$

\footnotetext{
${ }^{122}$ Hansard, HC Standing Committee B, 14 May 2002, cols 663-4; HL Vol 638, cols 828-31; HL Vol 639 , cols 1132-43. Those in parliament who supported an unqualified duty also argued that, on the assumption that the rising trend of bankruptcies continues, greater scrutiny is needed to prevent abuse of the system.

${ }^{123}$ A bankruptcy arising from a debtor's own petition where unsecured bankruptcy debts were less than the small bankruptcies level (formerly £20,000): see IA, s 275 repealed from 1 April 2004.

${ }^{124}$ IA, s 293.
} 


\section{E. Post-Discharge Restrictions ${ }^{125}$}

\section{Introduction}

As we have seen, the principal object of the reforms is to provide honest and unfortunate debtors with a fresh start free from the burden of indebtedness and from stigma, while at the same time penalising the dishonest and irresponsible minority. ${ }^{126}$ The means chosen to differentiate the "good" from the "bad" is the post-discharge restrictions regime found in section $281 \mathrm{~A}$ of, and Schedule $4 \mathrm{~A}$ to, the Insolvency Act. $^{127}$ Schedule $4 \mathrm{~A}$ is modelled on the civil disqualification regime in sections 6-9 of, and Schedule 1 to, the Company Directors' Disqualification Act 1986 ("CDDA"). As between the bankrupt and his creditors, the regime has no effect. All bankrupts are prima facie entitled to automatic discharge regardless of their conduct. ${ }^{128}$ The object of the regime is to impose restrictions and disabilities on those whose conduct merits it and thereby protect the public in the future from bankrupts who have acted recklessly, irresponsibly or dishonestly. The theory is that, while such bankrupts will still generally be released from their debts, they should be subjected to continuing restrictions beyond discharge in order to protect the public from any repetition of their misconduct. It is suggested that, in its attempt to differentiate the "honest" from the "culpable", the underlying purpose of regime is to send more sophisticated messages to the credit markets. The Secretary of State is required to enter details of all bankruptcy orders and all IVAs of which she receives notice ${ }^{129}$ onto the individual insolvency register. ${ }^{130}$ She is also required to maintain a bankruptcy restrictions register on which must be entered the details of any bankrupt who is made the subject

\footnotetext{
${ }^{125}$ See further A Walters and M Davis-White, Directors' Disqualification and Bankruptcy Restrictions (London, Sweet and Maxwell, $2^{\text {nd }}$ ed, 2004). See also, McKenzie Skene, supra n 12.

${ }_{126}$ Fresh Start from para 7.14; Second Chance from para 1.25 .

${ }^{127}$ Inserted by Enterprise Act 2002, s 257, Sch 4A. It should be pointed out that, while the means chosen are novel, this is not the first legislative attempt to differentiate between "good" and "bad" bankrupts. The first English statute to provide a discharge from bankruptcy debts, 4 Anne, ch 17 (1705), also mandated the imposition of the death penalty on those who had committed fraud. Certificates of conformity (Bankruptcy Consolidation Act 1849) and certificates of misfortune (Bankruptcy Act 1883) were similarly motivated.

${ }^{128}$ Section C1, supra.

${ }^{129}$ IR, r 5.29 .

${ }^{130}$ IR, rr 6A.1-5.
} 
of post-discharge restrictions. ${ }^{131}$ Both registers are open to public inspection and it is intended that they will be maintained in a single, searchable online database that makes it clear that the two registers are separate. All information concerning a bankruptcy must be deleted from the individual insolvency register once three months has elapsed from the date of discharge. ${ }^{132}$ Previously, the information could stay on the register for two years after discharge. ${ }^{133}$ Thus, there is an open invitation to credit providers to adjust their lending practices so as not to tar all bankrupts with the same brush. ${ }^{134}$ As the foreword to the Fresh Start consultation paper put it: "[w]e believe that a distinction can and should be made...so that the vast majority of honest bankrupts do not continue to be stigmatised through association with the dishonest". ${ }^{135}$ Whether this means that credit providers will adopt a more generous approach to bankrupts that the law (by exclusion) labels as "honest" may depend on their attitude to the fact of bankruptcy per se and on how much faith they are prepared to place in the information that the bankruptcy system provides. Ultimately, the legal system will label a bankrupt as "honest" by virtue of the fact that the Insolvency Service chooses not to take action under the post-discharge restrictions regime. If the desired result is to be achieved, lenders will need to be confident that the line between the "honest" and the "culpable" is being drawn in the right place. ${ }^{136}$

\section{The present scope of post-discharge restrictions}

The court may make a bankruptcy restrictions order ("BRO") on the application of either the Secretary of State or the official receiver acting on a direction of the Secretary of State. ${ }^{137}$ The Secretary of State also has power to accept a bankruptcy restrictions undertaking ("BRU”) equivalent in effect to a BRO. Where the bankrupt consents to post-discharge restrictions and the parties are able to agree on the period

\footnotetext{
${ }^{131}$ IA, Sch 4A, para 12; IR, rr 6.A.1(2), 6.A6-7.

${ }^{132}$ IR, r 6A.5(b).

${ }^{133}$ IR, r 6.223(A)(4) revoked by the Insolvency (Amendment) Rules 2003 SI 2003/1730.

${ }^{134}$ There is scope also for the development of credit rating models that differentiate between bankrupts who are the subject of post-discharge restrictions as the period for which the restrictions are imposed must be recorded in the bankruptcy restrictions register and, in theory, the longer the period, the more severe the case.

${ }^{135}$ For a fuller extract see Section A, supra.

${ }^{136}$ The current practice of the credit reference agencies is to keep details of bankruptcies on file for six years: see No Credit?, a public information pamphlet produced by the Information Commissioner. The six years reflects the standard limitation period for an action on a debt.

${ }^{137}$ IA, Sch 4A, para 1. References to the Secretary of State hereafter include a reference to the official receiver.
} 
for which the restrictions should apply, the case can be disposed of by means of a BRU without the involvement of the court. The BRU system is designed to provide a convenient and cost-effective alternative to court proceedings and is modelled on the system of disqualification undertakings that operates under the CDDA. ${ }^{138}$ BROs and BRUs can be made for a period of between two and 15 years. ${ }^{139}$ A person subject to a BRO or a BRU will be prevented on pain of criminal penalty from acting in the following capacities for so long as the order or undertaking is in force: ${ }^{140}$ company director (without the court's permission), ${ }^{141}$ insolvency practitioner, ${ }^{142}$ receiver or manager of a company's property, ${ }^{143}$ member of parliament, ${ }^{144}$ member of a local authority $^{145}$ and member of the Valuation Tribunal Service. ${ }^{146}$ Such a person is also subject to the prohibition on obtaining credit above the prescribed amount without disclosure of status. ${ }^{147}$ It is anticipated that the Secretary of State will use the power in section 268 of the Enterprise Act to amend provisions in other legislation (for example, charities and pensions legislation) so as to further increase the scope of bankruptcy restrictions and bring the regime into conformity with the wider consequences of directors' disqualification under the CDDA. ${ }^{148}$

\section{Identifying “culpable” bankrupts}

The process of identifying so-called "culpable bankrupts" has been left entirely to the Insolvency Service and the courts in light of their experience of operating the directors' disqualification regime. The structural similarity between the "unfit conduct" provisions in CDDA, ss 6-9 and Sch 1 is striking and, it is suggested, deliberate. ${ }^{149}$ As a result, although the policy rhetoric has often sounded American,

\footnotetext{
${ }^{138}$ See Walters, supra n 93; Walters and Davis-White, supra n 125, ch 9.

${ }^{139}$ IA, Sch 4A, paras 4(2), 9(2).

${ }^{140}$ The list is non-exhaustive. NB any enactment that expressly refers to a person who is the subject of a BRO includes a reference to a person the subject of a BRU: IA, Sch 4A, para 8.

${ }^{141}$ CDDA, s 11(1) (as substituted by Enterprise Act 2002, s 257(3), Sch 21, para 5).

${ }^{142}$ IA, ss 390(5) (as inserted by Enterprise Act 2002, s 257(3) and Sch 21, para 4), 389(1).

${ }^{143}$ IA, s 31 (as substituted by the Enterprise Act 2002, s 257(3) and Sch 21, para 1).

${ }^{144}$ IA, s 426A (as inserted by the Enterprise Act 2002, s 266).

${ }^{145}$ Local Government Act 1972, s 80(1)(b) (as substituted by Enterprise Act 2002, s 267).

${ }^{146}$ Local Government Act 2003, s 105 and Sch 4, para 2(1)(b). Under the Railways and Transport Safety Act 2003, s 15 and Sch 1, para 2(c), the making of a BRO is grounds for removal from membership of the Office of Railway Regulation.

${ }^{147}$ IA, s 360(5) (inserted by the Enterprise Act 2002, s 257(3) and Sch 21, para 3).

${ }^{148}$ On the wider consequences of CDDA disqualification under, inter alia, charities, pensions, police and education legislation, see Walters and Davis-White, supra n 125, ch 14.

${ }^{149}$ Second Chance, para 1.27.
} 
the implementation is rooted in the English tradition of administrative scrutiny of debtors in the public interest. ${ }^{150}$

In deciding whether to bring proceedings for a BRO, the Secretary of State is not expressly required by Schedule 4A to consider whether it is expedient in the public interest that a BRO should be made. This contrasts with the position under sections $7(1)$ and $8(1)$ of the CDDA in relation to the commencement of civil directors' disqualification proceedings on grounds of unfit conduct. It is suggested that this is simply a matter of drafting style. The imposition of an express public interest requirement is strictly superfluous as, in practice, and as a matter of general administrative law, the Secretary of State is bound to apply public interest criteria in determining whether or not to proceed. ${ }^{151}$ Experience under the CDDA suggests that the Insolvency Service and the courts will regard the Secretary of State's role under the post-discharge restrictions regime as similar, if not identical, to her role in directors' disqualification proceedings. It follows that the courts are likely to be slow to substitute their judgment as to whether the public interest required the proceedings to be commenced or continued for that of the Secretary of State. ${ }^{152}$

Schedule 4A, para 2(1) provides that the court "shall grant an application for a BRO if it thinks it appropriate having regard to the conduct of the bankrupt (whether before or after the making of the bankruptcy order)." Despite the use of the word "shall", it is for the court to decide in its discretion whether a BRO is "appropriate" in the light of the bankrupt's conduct and all the relevant circumstances. It is suggested that the courts are likely to follow the approach taken in proceedings under section 8 of the CDDA where, although the power to disqualify is discretionary, the courts have indicated that it will be rare, in the event of proven misconduct, for the discretion to be exercised against the making of an order. ${ }^{153}$ Moreover, the courts are likely to be circumspect in deciding, as a matter of discretion, that an order should not be made because (for example) the bankrupt has since "learned his lesson". 154

\footnotetext{
${ }^{150}$ Section B1, supra.

${ }^{151}$ See further Fresh Start, para 7.15; Second Chance, para 1.29. Such criteria are likely to include the degree of harm that the bankrupt by his conduct has inflicted on creditors and the likelihood that such conduct will be repeated.

${ }^{152}$ See, by analogy, Re Blackspur Group plc, Secretary of State for Trade and Industry v Davies [1998] 1 WLR 422; Re Blackspur Group plc, Secretary of State for Trade and Industry v Eastaway [2002] 2 BCLC 263.

${ }^{153}$ Walters and Davis-White, supra n 125 from para 4-07.

${ }^{154}$ See, by analogy, Re Grayan Building Services Ltd, Secretary of State for Trade and Industry $v$ Gray [1995] Ch 241, 254.
} 
It is striking that Schedule 4, para 2 contains no equivalent of the basic threshold requirement in CDDA, ss 6(1) and 8(2) that the person's conduct makes him "unfit". Thus, although a person subject to a BRO is disqualified, among other things, from acting as a director, the appropriateness of a BRO does not expressly depend on whether or not the person is unfit to engage in the restricted activities and capacities. The lack of any threshold requirement beyond "appropriateness" means that the question the court must decide under Schedule 4A, para 2 is broader than its counterpart under CDDA, ss 6(1) and 8(2). In effect, the court must determine whether it is appropriate on the evidence of the individual's conduct that he be subjected to continuing restrictions in the public interest. Moreover, the court is required to consider the "conduct of the bankrupt" which is potentially wide in scope, whereas under the CDDA, ss 6(1) and 8(2), the court may only consider (respectively) the defendant's "conduct as a director" of the company or "conduct in relation to the company". Nevertheless the conduct must at least be relevant to the bankruptcy and to the purpose of the regime. So the fact, for example, that the bankrupt also happens to be a dangerous motorist would clearly not be relevant. Given the width of the prohibitions that currently flow from bankruptcy restrictions, it is suggested that it is not feasible for the court to ask whether the bankrupt's conduct is such as to require him to be subjected to each and every prohibition. Instead, as in the CDDA context, the courts are likely to formulate the test more widely in the terms of a failure to meet required standards. ${ }^{155}$

Schedule 4A, para 2(1) provides that the court can take into account the bankrupt's conduct either before or after the making of the bankruptcy order. Thus, the Secretary of State could conceivably target (i) conduct that occurred before the date of the bankruptcy petition and/or (ii) conduct that occurred in the period between the date of the petition and the date of the order ${ }^{156}$ and/or (iii) conduct that occurred or is occurring after the commencement of bankruptcy. It is important to note that, for transitional purposes, the court may only take into account conduct that occurred after 1 April 2004. ${ }^{157}$ However, this does not rule out the possibility that a BRO could be imposed on a person whose bankruptcy commenced on or before 1 April 2004 as long

\footnotetext{
${ }^{155}$ See Re Grayan Building Services Ltd, Secretary of State for Trade and Industry v Gray [1995] Ch 241.

${ }^{156}$ The so-called "initial period" defined in IA, s 351(b) for the purposes of the bankruptcy offences in that part of the Act.

${ }^{157}$ Commencement Order, art 7.
} 
as the bankruptcy was still continuing at that date. This is because the court can rely on misconduct during the bankruptcy, such as non-cooperation with the official receiver or trustee, which continued after 1 April 2004.

Schedule 4A, para 2(1) is amplified by paragraph 2(2) which provides that "the court shall, in particular, take into account" any of thirteen specified kinds of behaviour on the part of the bankrupt. Taken collectively, the sheer width of paragraph 2(2) is striking. The kinds of behaviour identified range from downright dishonesty to lesser states of culpability such as negligence, recklessness, incompetence and extravagance. In keeping with the point made earlier in Section B, they are capable of embracing misconduct by consumer as well as business bankrupts. ${ }^{158}$ Although the court is required to take into account the various matters that are specifically mentioned, the use of the expression "in particular" makes it clear that paragraph 2 was not intended to be exhaustive. ${ }^{159}$ This mirrors the position in relation to CDDA, ss 6 to 9 and Sch $1 .{ }^{160}$ So, while not expressly mentioned, the court could presumably take into account, for example, conduct the subject matter of existing criminal offences (such as obtaining credit without disclosure of status in contravention of section 360(1)(a) of the Insolvency Act) or the bankrupt's conduct during the course of a failed IVA where the bankruptcy order was made on a supervisor's petition. ${ }^{161}$ There is no specific guidance in Schedule $4 \mathrm{~A}$ as to the degree of misconduct that will make a BRO appropriate nor is there any indication of the relative weight that the court should give to the various kinds of behaviour specified in paragraph 2(2). It is also unclear whether the specified kinds of behaviour should be given greater weight than other kinds of culpable behaviour that are not specifically mentioned. None of this should come as any surprise given the difficulty of producing a comprehensive legislative definition of "culpable behaviour" and the need for the law to be flexible enough to respond to changing patterns of misconduct over time. Accordingly, the policy behind Schedule 4A rests on the premise that it is

\footnotetext{
${ }^{158}$ See, in particular, IA, Sch 4A, paras 2(2)(h) (incurring, before commencement of bankruptcy, a debt which the bankrupt had no reasonable expectation of being able to pay) and 2(2)(j) (unreasonable extravagance).

${ }^{159}$ Fresh Start, para 7.16 confirms that the list of specific matters of misconduct was intended to be "non-exhaustive". Second Chance, para 1.30 refers to a "statutory but non-exhaustive schedule of unfitted conduct". See also Hansard, HC Standing Committee B, 14 May 2002 at col 654.

${ }^{160}$ See Re Migration Services Ltd, Official Receiver v Webster [2000] BCC 1095; Walters and DavisWhite, supra n 125, chs 4-5.

${ }^{161}$ This could include the making of false representations to procure approval of an IVA contrary to IA, s. 262A.
} 
best to rely on the expertise and experience of the Secretary of State (through the Insolvency Service) and, ultimately, the judgment of the courts on the merits of individual cases to perform the task of differentiating culpable from non-culpable bankrupts. ${ }^{162}$ It cannot be emphasised enough that much will depend on the particular circumstances of each case.

Subject to the caveat that the exercise of the jurisdiction will inevitably be highly fact-sensitive, the following additional points can be made concerning the specific contents of paragraph 2(2) and the direction in which the law is likely to develop:

(1) Several of the kinds of behaviour specified in paragraph 2(2) are identical to or based on the grounds on which the court could formerly refuse to discharge an individual from bankruptcy under the Bankruptcy Acts 1883 and 1914. ${ }^{163}$ The post-discharge restrictions regime is therefore rooted in the tradition of the old bankruptcy legislation: a case of "back to the future".

(2) In relation to the specific references in paragraph 2(2) to preferences, transactions at undervalue and excessive pension contributions, it is suggested that the court could take into account relevant conduct without the Secretary of State having to establish all the elements that a trustee in bankruptcy would be required to establish in civil recovery proceedings under sections 339,340 and $342 \mathrm{~A}$ of the Insolvency Act. ${ }^{164}$ Even so, the question of whether a BRO is appropriate will depend on the seriousness of the conduct and, in this respect, it seems clear that, for example, a deliberate strategy of paying off debts owing to friends and relatives, would be regarded as more culpable than a decision to pay one or two pressing creditors who were at arms' length.

(3) Failure to supply goods or services having accepted a customer pre-payment (para 2(2)(f)) and continuing to trade with actual or constructive knowledge of insolvency (para $2(2)(\mathrm{g})$ ) are matters that can also be taken into account by the courts in determining whether a director's conduct makes him unfit to be

\footnotetext{
${ }^{162}$ See Hansard, HC Standing Committee B, 14 May 2002 at cols 638 and 655.

${ }^{163}$ See Bankruptcy Act 1883, s 28; Bankruptcy Act 1914, s 26 and for background see Cork Report, paras $115-43$

${ }^{164}$ See, by analogy, Re Sykes (Butchers) Ltd, Secretary of State for Trade and Industry v Richardson [1998] BCC 484.
} 
concerned in the management of a company for the purposes of CDDA, s $6 .{ }^{165}$ It seems likely that the court's approach to these types of misconduct under the CDDA will influence the approach to similar conduct under the post-discharge restrictions regime (and, in time, vice versa).

(4) Continuing to trade with actual or constructive knowledge of insolvency (para $2(2)(\mathrm{g}))$ and incurring before commencement of bankruptcy a debt which the bankrupt had no reasonable expectation of being able to pay (para 2(2)(h)) appear to be overlapping forms of misconduct. However, the former only applies to traders whereas the latter is capable of applying to both traders and consumer bankrupts. Thus, for example, if an individual takes out a personal loan knowing that he has insufficient income to meet the monthly repayments, such conduct would apparently fall within Schedule 4A, para $2(2)(\mathrm{h})) .{ }^{166}$ The same is true of individuals who deliberately load expenditure onto credit cards on the eve of bankruptcy. Furthermore, the incurring of a single debt (as opposed to a series of debts) is sufficient to fall within the wording. This does not mean that the incurring of a single debt in the circumstances described will necessarily result in the imposition of a BRO. The court will need to evaluate the bankrupt's conduct in the round and decide whether there is sufficient misconduct to justify a BRO and, by implication, the denial of a complete fresh start free from the stigma of bankruptcy restrictions.

(5) There is some overlap between paragraph 2(2) and the bankruptcy offences in Part IX, Chapter 6 of the Insolvency Act (starting at section 350):

(a) Failure to keep records which account for a loss (para 2(2)(a)) overlaps to some extent with the offence of failure without reasonable excuse to account for or give a satisfactory explanation of the loss of any substantial part of the bankrupt's property in section 354(3) of the Insolvency Act.

\footnotetext{
${ }^{165}$ Walters and Davis-White, supra n 125, chs 4-5.

${ }^{166}$ As would the taking out of a consolidation loan where all of the individual's debts are consolidated into a single debt and the individual knows that he still cannot meet the repayment terms.
} 
(b) The term "fraud" (para 2(2)(1)) is clearly capable of encompassing conduct of the following kind: (i) non-disclosure or concealment by the bankrupt of property comprised in his estate to the official receiver or trustee in bankruptcy; ${ }^{167}$ (ii) concealment, destruction, falsification or alteration by the bankrupt of books and records relating to his estate and affairs; ${ }^{168}$ (iii) false statements by the bankrupt relating to his affairs; ${ }^{169}$ (iv) the fraudulent disposal or concealment by the bankrupt of his property; ${ }^{170}$ (v) absconding with property; ${ }^{171}$ (vi) fraudulent dealing by the bankrupt with property that he had obtained on credit. ${ }^{172}$ Where the conduct that could be targeted as a possible offence under these provisions occurs after the commencement of bankruptcy (for example, non-disclosure of property in contravention of Insolvency Act, s 353), it could also be classified as failure to co-operate with the official receiver or trustee in bankruptcy (para 2(2)(m)).

(c) The offence of gambling or rash and hazardous speculation formerly contained section 362 of the Insolvency Act has been repealed ${ }^{173}$ but is now mirrored in paragraph 2(2)(j) and extended to cover "unreasonable extravagance".

Where there is evidence of misconduct suggesting, prima facie, that a bankruptcy offence under the Insolvency Act has been committed, there will also be a strong prima facie case for a BRO, especially where, for example, the bankrupt has disposed of or concealed assets that form part of his estate to the detriment of his creditors. One problem for the Secretary of State is that the criminal courts have no power equivalent to CDDA, s 2 to impose a BRO following conviction for a bankruptcy offence. The Secretary of State may therefore be forced to consider applying to the civil courts for a BRO in cases where a criminal prosecution has been commenced or is being contemplated. In any event, the Secretary of State

\footnotetext{
${ }^{167}$ IA, ss 353-4.

${ }^{168}$ Ibid, s 355.

${ }^{169}$ Ibid, s 356.

${ }^{170}$ Ibid, s 357.

${ }^{171}$ Ibid, s 358.

${ }^{172}$ Ibid, s 359.

${ }^{173}$ Also from 1 April 2004: Enterprise Act 2002, s 263(b); Commencement Order, art 2(2), Sch 2.
} 
may take the view that a BRO is necessary to protect the public while the criminal trial is pending. Thus, there is scope for parallel proceedings. Equally, given the lower standard of proof in civil proceedings, BROs could become the weapon of choice for dealing with bankrupts whose conduct falls within the scope of the bankruptcy offences. ${ }^{174}$

(6) Paragraph 2(2)(m) reinforces the bankrupt's obligations in sections 291 and 333 of the Insolvency Act to co-operate with the official receiver and his trustee in bankruptcy. These obligations are central to the proper functioning of the bankruptcy system. The bankrupt's co-operation is vital to the identification and collection of his assets, the determination of his liabilities and the provision of information concerning his affairs. While a bankruptcy is still live, the official receiver and the trustee in bankruptcy have a clear interest in compelling the bankrupt to co-operate for the benefit of the estate. The principal means of enforcement is an application to the court under section 279(3) of the Insolvency Act to suspend the bankrupt's discharge on the ground that the bankrupt has failed or is failing to co-operate. ${ }^{175}$ Suspension of discharge is a powerful sanction as, until the suspension is lifted, the one-year discharge period in section 279(1) ceases to run. Accordingly, the information and asset-gathering provisions of the Insolvency Act that apply up to discharge would continue to have effect. Time will also stop running for the purposes of an application for a BRO. ${ }^{176}$ As such, an application for suspension will always be the weapon of first resort. Once the suspension is lifted, it is conceivable that the Secretary of State could rely on the bankrupt's previous failure to co-operate as a ground for a BRO either (i) on a cumulative basis where other kinds of misconduct have come to light in the meantime or (ii) on its own where the failure to co-operate has caused obvious harm to the bankrupt's creditors. ${ }^{177}$ It is as yet unclear whether the Secretary of State would seek to rely on the bankrupt's failure to co-operate where such failure had not been regarded as sufficiently serious to merit an application for suspension of discharge. It seems unlikely that a lesser degree of uncooperative

\footnotetext{
${ }^{174}$ See Second Chance, para 1.26 and Annex D, para 2.3.

${ }^{175}$ See Section C1, supra.

${ }^{176}$ Which application must generally be brought within the one-year period before automatic discharge: see further Section E6, infra.

${ }^{177}$ See, by analogy, CDDA, s 9; Sch 1, Pt II, para 10 and Re Copecrest Ltd, Secretary of State for Trade and Industry $v$ McTighe (No 2) [1997] BCC 224.
} 
behaviour would give adequate grounds for a BRO although, as has already been stressed, much will depend on the circumstances of the case.

(7) Paragraph 2(2)(k) (neglect of business affairs of a kind which may have materially contributed to or increased the extent of the bankruptcy) permits the court to take into account incompetence on the part of a bankrupt trader. Bearing in mind that paragraph 2(2) is not exhaustive, it is conceivable that the court could impose a BRO on a bankrupt (trader or consumer) where there is evidence of demonstrable inability to manage personal financial affairs. This is especially so where the bankrupt's incompetence has caused harm to his creditors or is of such a degree that he poses a significant risk to the public. ${ }^{178}$

(8) Given the width of paragraph 2(2) and the fact that the matters expressly mentioned are not exhaustive, one intriguing question is whether the court could consider the conduct of the bankrupt in his capacity as a director of a company for the purposes of determining an application for a BRO. The question could arise in circumstances where a director of an insolvent company is subsequently bankrupted having defaulted on a personal guarantee of the company's indebtedness. It is suggested that the court determining the BRO application should not generally focus on the person's conduct as a director of the company because (i) this is a matter for separate proceedings under CDDA, s 6 and (ii) read as a whole, Schedule 4A, para 2 is concerned with conduct both before and during the bankruptcy that relates to or affects the bankruptcy estate. There may be hybrid cases in which it is not easy to draw the line. One example is where the director's neglect of the company's affairs was responsible for its default and, in turn, for the personal default that led to the director's bankruptcy. Even so, the point remains that conduct as a director is strictly a CDDA matter. As a result, the Secretary of State may be faced with a tactical decision whether to apply for a BRO or proceed under the CDDA (or both). No doubt, that decision will turn on the relative seriousness of the relevant conduct that could be considered in each of the regimes.

\footnotetext{
${ }^{178}$ It was suggested in Fresh Start, paras 7.19-21 that bankrupts could be offered financial counselling on either a mandatory or optional basis. However, the idea was subsequently dropped: see Second Chance, para 1.5. On incompetence in the CDDA context see Walters and Davis-White, supra n 125, chs 4-5.
} 


\section{Repeat bankrupts}

We saw in Section C2 that a repeat bankrupt, meaning under the old law, a person who has been an undischarged bankrupt at any time in the period of 15 years ending with the commencement of his present bankruptcy, is no longer required to apply to court for discharge and from 1 April 2004 (subject to transitional provisions) is just as entitled to automatic discharge as a first-time bankrupt. The court is directed by Schedule 4A, para 2(3) to "consider whether the bankrupt was an undischarged bankrupt at some time during the period of six years ending with the date of the bankruptcy to which the application [for a BRO] relates." Thus, while no longer a reason for restricting the availability of discharge, a previous bankruptcy within six (rather than 15) years, is a matter that can be taken into account under the postdischarge restrictions regime. The wording appears to suggest that the court should take into account the mere fact of a previous bankruptcy. However, given that the fresh start policy has been extended to include repeat bankrupts, it seems inconceivable that the Secretary of State could rely on the fact of a previous bankruptcy, without more, as the basis for a BRO. ${ }^{179}$ Apart from the preservation of the court's jurisdiction to suspend discharge on grounds of the bankrupt's failure to co-operate, the reforms introduced by the Enterprise Act make it clear that discharge cannot generally be withheld because of misconduct and it certainly cannot be withheld simply because of a previous bankruptcy. The post-discharge restrictions regime is designed to stigmatise misconduct, not the fact of bankruptcy per se. Moreover, the overriding requirement in Schedule 4A is the requirement in paragraph 2(1) for the court to have regard to "the conduct of the bankrupt". It appears to follow that the reference to previous bankruptcy in paragraph 2(3) could be read as a reference to the bankrupt's conduct in the previous bankruptcy. Thus, in a case where there was relevant conduct in the first bankruptcy but the Secretary of State took the view that it was insufficient to justify a BRO, paragraph 2(3) may permit the court to consider the conduct in the first bankruptcy together with conduct in the subsequent bankruptcy on a cumulative basis. If so, it is likely that law and practice under the

\footnotetext{
${ }^{179}$ This reflects the government's policy as articulated by the Under-Secretary of State for Trade and Industry during the parliamentary debate: "We want to reduce the stigma for bankrupts, including those who may have failed before, as long as there is not misconduct." (Hansard, HC Standing Committee B, 14 May 2002, col 660).
} 
BRO regime in this respect will develop by analogy with law and practice under CDDA, s. 6 in relation to lead and collateral companies. ${ }^{180}$

\section{Commencement and duration of BROs/BRUs}

Schedule 4A, para 4(1) provides that a BRO shall come into force when it is made and shall cease to have effect at the end of a date specified in the order. By virtue of Schedule 4A, para 4(2), a BRO must be made for a period of at least two years but no more than 15 years, the same statutory parameters as for a disqualification order or undertaking under CDDA, s 6. It seems likely that the courts will divide the available period of two-to-fifteen years into brackets of over ten years (reserved for particularly serious cases), six to ten years (for serious cases not meriting the highest bracket) and two to five years (for less serious cases) by analogy with practice under the CDDA. ${ }^{181}$ The position in relation to BRUs is the same in all material respects. ${ }^{182}$

\section{Procedural issues}

An application for a BRO must be supported by a report from the Secretary of State. The report must include (i) a statement of the conduct by reference to which it is alleged that it is appropriate for a BRO to be made and (ii) the evidence on which the Secretary of State relies in support of the application. ${ }^{183}$ Where the applicant is the official receiver, the report is prima facie evidence of any matter contained in it. ${ }^{184}$ The Insolvency Rules set out a timetable for the filing of evidence and the hearing of the application. ${ }^{185}$

An application for a BRO must be made before the end of the period of one year beginning with the date on which the bankruptcy commenced unless the bankrupt's discharge is suspended under section 279(3) of the Insolvency Act in which case the one-year period will cease to run. ${ }^{186}$ Once the one-year period has expired an

\footnotetext{
${ }^{180}$ See Re Country Farm Inns Ltd, Secretary of State for Trade and Industry v Ivens [1997] BCC 801; Walters and Davis-White, supra n 125, ch 3.

${ }^{181}$ See Re Sevenoaks Stationers (Retail) Ltd [1991] Ch 164.

${ }^{182}$ IA, Sch 4A, paras 7-9.

${ }^{183}$ IR, r 6.241. Further procedural matters are dealt with in rules 6.242-4.

${ }^{184}$ Ibid, r 7.9(3).

${ }^{185}$ Ibid, rr 6.240-4.

${ }^{186}$ IA, Sch 4A, para 3(1)(a), (2).
} 
application can only be made with the permission of the court. ${ }^{187}$ The onus is on the Secretary of State to satisfy the court that permission should be granted. ${ }^{188}$ It is anticipated that the courts will approach such applications on a similar basis to applications for permission to commence proceedings for a disqualification order under CDDA, s 6 after the expiry of the two-year period in CDDA, s 7(2), ${ }^{189}$ although there is likely to be some adjustment to reflect the purpose and spirit of the Enterprise Act. The policy is that an application should normally be made before the bankrupt's discharge under section 279, hence the alignment of the one-year period of bankruptcy with the one-year time limit for a BRO application without the court's permission. ${ }^{190}$ Thus, a bankrupt can generally expect to be free of his debts and free from restrictions after a year in accordance with the "fresh start" policy. The primary concern of the Enterprise Act for the rehabilitation of the debtor suggests that the risk to the public will need to be considerable before the court will grant the Secretary of State permission to bring an application for a BRO out of time although each case will turn on its own facts. It follows that any negotiations for a BRU will need to be initiated sufficiently early so as to allow time for an application to the court should those negotiations prove to be unsuccessful.

Any time between the institution and determination of an application for a BRO, the court has the power to make an interim BRO identical in effect to a BRO or BRU if the court thinks that (i) there are prima facie grounds to suggest that the application for the BRO will be successful and (ii) it is in the public interest to make the interim order. ${ }^{191}$ The purpose of interim BROs is to deal with the position where the Secretary of State applies for a full BRO late within the one-year period and it is not administratively possible for the application to be heard before the date on which the

\footnotetext{
${ }^{187}$ Ibid, Sch 4A, para 3(1)(b).

${ }^{188}$ See, by analogy, Re Copecrest Ltd, Secretary of State for Trade and Industry $v$ McTighe [1993] BCC 844, 852; Re Blackspur Group plc, Secretary of State for Trade and Industry v. Davies (No. 2) [1996] 4 All ER 289, 296.

${ }_{189}$ For the relevant principles see Walters and Davis-White, supra n 125 , ch 8.

${ }^{190}$ The court is unlikely to be sympathetic simply because the applicant has only one year to make the application compared with two years under the CDDA, s. 7. Apart from the case of companies in compulsory liquidation where the official receiver is initially involved, information gathering in CDDA, s 6 cases is dependent on reports from insolvency practitioners. In practice, the reporting procedures may absorb a considerable part of the two-year period in CDDA, s 7(2). Information gathering for BROs is carried out by the official receiver in accordance with the Insolvency Service's vetting procedures and is not dependent on insolvency practitioner reporting, although the trustee in bankruptcy is obliged to provide such information and assistance as the official receiver may reasonably require under IA, s 305(3).

${ }^{191}$ See generally IA, Sch 4A, paras 5-6. Procedure is governed by IR, rr 6.245-7.
} 
bankrupt is automatically discharged. ${ }^{192}$ In the absence of the interim BRO procedure to cover this eventuality, there would be a gap during which the individual would be free from bankruptcy restrictions. It is important to note that the Secretary of State cannot use the interim BRO procedure to buy time in which to pursue further investigations. As already explained, an interim BRO can only be made where an application for a full BRO is on foot and there is a prima facie case. In practice, it is suggested that the courts will treat the application as one for an interim injunction and apply a balance of convenience test. In other words, it is likely that the court will require to be satisfied that the alleged misconduct is so serious that the overall balance of the public interest lies in favour of making the order. As a matter of the domestic law applicable to interim injunctions, it seems unlikely that cross-undertakings in damages will be required from the Secretary of State given that she is acting in a law enforcement role. ${ }^{193}$ However, the absence of a cross-undertaking may raise the standard of proof with regard to the need for interim protection and weigh in the balance of convenience against the grant of an interim BRO because, if a final BRO is ultimately refused and the interim BRO should not have been made, the bankrupt may suffer damage that is not remediable. ${ }^{194}$

\section{The effect of annulment}

Where a bankruptcy order is annulled under section 282(1)(a) of the Insolvency Act on the ground that the order ought not to have been made, any BRO, interim BRO or BRU then in force must also be annulled and the former bankrupt cannot be made the subject of a new BRO, interim BRO or undertaking. ${ }^{195}$ However, where a bankruptcy order is annulled following either the approval of a post-bankruptcy IVA ${ }^{196}$ or the

\footnotetext{
${ }^{192}$ Hansard, HC Standing Committee B, 14 May 2002 at cols 661-2. It was suggested in Fresh Start, para 7.15 that discharge from bankruptcy would be suspended pending determination of a BRO. However, this approach has not been pursued presumably because it would penalise bankrupts on the basis of delays outside their control. The procedure puts the onus on the Secretary of State to make a prima facie case for a full $\mathrm{BRO}$ as a pre-condition for an interim $\mathrm{BRO}$.

${ }^{193}$ Hoffmann-La Roche \& Co AG v Secretary of State for Trade and Industry [1975] AC 295; Re Highfield Commodities Ltd [1985] 1 WLR 149; Kirklees Metropolitan Borough Council v Wickes Buildings Supplies Ltd [1993] AC 227; Securities and Investments Board v Lloyd-Wright [1993] 4 All ER 210.

${ }^{194}$ See Customs and Excise Commissioners v Anchor Foods Ltd [1999] 1 WLR 1139 at 1150E-F.

${ }^{195}$ IA, Sch 4A, para 10. The same applies to a bankruptcy order annulled under IA, s 282(2).

${ }^{196}$ Ibid, ss 261 and 263D.
} 
paying of all the bankruptcy debts and expenses, ${ }^{197}$ the annulment has no effect on any BRO, interim BRO or BRU already in force. ${ }^{198}$ Also, the court has the power to make a BRO and the Secretary of State to accept a BRU in such a case as long as the application was instituted or the BRU offered before the annulment. ${ }^{199}$ The underlying policy is that a bankrupt should not be able to buy his way out of a BRO.

\section{Costs}

Civil disqualification proceedings under the CDDA are free standing proceedings and the costs usually follow the event. ${ }^{200}$ This means that if the Secretary of State succeeds in obtaining a disqualification order, the director will be ordered to pay costs. As the Secretary of State does not currently require the disqualified person to agree to pay the administrative costs incurred in processing his case as a condition of accepting a disqualification undertaking where the need to issue proceedings is avoided, there is a powerful costs incentive for directors to seek a compromise by means of undertaking. It appears that the position in relation to BROs may be different. An application for a BRO is an ordinary application in the bankruptcy rather than a free standing application. Where an application is made in bankruptcy, the usual order is that any costs will be borne by the bankruptcy estate. This practice is unlikely to be followed in the case of BROs as the public protection provided by the order would effectively be purchased at the expense of the bankrupt's creditors. An alternative would be to order the bankrupt to pay the Secretary of State's costs on the basis that it is the bankrupt's misconduct that occasioned the application. This is a possibility. However, it cuts against the policy of relieving indebtedness regardless of conduct $^{201}$ and, it is arguable that if the bankrupt has available income, this should be captured for the estate through an IPO or IPA rather than being absorbed by costs. It follows that the costs may have to be borne, in the first instance, by the Insolvency Service which will therefore want to maximise the use of BRUs. ${ }^{202}$ Given the

\footnotetext{
${ }^{197}$ Ibid, s. 282(1)(b).

${ }^{198}$ Ibid, Sch. 4A, para 11(a).

${ }^{199}$ Ibid, Sch. 4A, para 11(b)-(d).

${ }^{200}$ Walters and Davis-White, supra n. 126, ch. 7.

${ }^{201}$ Sections C1 and E1, supra.

${ }^{202}$ Disqualification undertakings were introduced (by the Insolvency Act 2000) against a background of the voluminous and settled case law generated by the CDDA from 1986 onwards. In contrast, BRUs have been introduced at the same time as BROs without any body of case law having been established. One danger for the Insolvency Service is that BRUs accepted early in the life of the regime may be
} 
budgetary implications and the need for there to be clear incentives for bankrupts to make maximum use of BRUs, there are practical arguments in favour of the Secretary of State being awarded costs in the event that a BRO is made. ${ }^{203}$ However, public indications have been given in practitioner forums that the Secretary of State will not seek costs in those circumstances.

\section{Summary}

The principal source of discipline in bankruptcy is now the post-discharge restrictions regime. As is the case with civil disqualification under the CDDA, the object of the exercise is to single out and sanction those whose conduct makes them a risk to the public. The system is designed to generate broad standards from the raw material of individual cases and it is expected that patterns will emerge over time in terms of the types of misconduct most likely to be targeted by the Insolvency Service and the courts. There are various shades of "culpable" bankrupt ranging from the dishonest and fraudulent to the incompetent and extravagant but ultimately the imposition of bankruptcy restrictions is likely to depend as much on the seriousness and extent of the conduct on the facts of individual cases as on its classification according to a hypothetical sliding scale of culpable states. It appears that the regime will have to be funded out of public expenditure and this begs the question: what are we paying for? The answer seems to be: the hope that the public's attitude meaning, in particular, the attitude of lenders to bankrupts who are not subjected to bankruptcy restrictions will become more relaxed. The realisation of the policy therefore depends on the response of credit markets and the extent to which former bankrupts are able to reacquire affordable credit. The regime will clearly provide the markets with more information. However, there is, of course, no guarantee that the markets will respond ways that government desires. Put crudely, there is nothing to stop the markets rating bankrupts

challenged under IA, Sch 4A, para 9(3)(a) if a court, on similar facts, declines to make a BRO (or makes a BRO for a shorter period) in a subsequently decided case.

${ }^{203}$ The Regulatory Impact Assessment anticipates that the cost to the Insolvency Service of the new procedures "will be met in part by refocusing investigative resources" but concedes that more specialist examining staff are needed (para 6.22). It also anticipates that through increased numbers of cases, including prosecutions for breach of BROs and BRUs, the bankruptcy restrictions regime will impact on the court system (paras 6.24-6.25). However, on the assumption that only $50 \%$ of cases will require a hearing (the rest being settled by BRUs), and taking into account possible savings elsewhere (achieved through the introduction of IPAs in bankruptcy and out-of-court administration procedures in corporate insolvency), the overall impact on the courts was expected to be marginal. The effectiveness of the new legislation is to be monitored after it has been in force for three years (para 11.2). 
as "bad" and bankrupts the subject of BROs or BRUs as (in varying degrees) "worse", although it may prove to be significant that basic bankruptcy information will only appear on the individual insolvency register for up to a maximum of 15 months in a run-of-the-mill case. ${ }^{204}$

\section{F. POST-BANKRUPTCY INDIVIDUAL VOLUNTARY ARRANGEMENTS}

The Enterprise Act 2002, s 264 and Sch 22 introduced as sections 263A-G and 389B of the Insolvency Act a new set of provisions establishing a "fast-track" IVA procedure administered exclusively by the official receiver, who for the first time, is authorised to act as nominee or supervisor in relation to an IVA. The procedure is only available to debtors who are already bankrupt and the official receiver must be specified in the proposal as the nominee. ${ }^{205}$ The proposal must set out the terms of the proposed IVA, a statement of the debtor's affairs and an explanation from the official receiver as to why, in his opinion, an IVA is desirable, giving reasons why the creditors may be expected to approve it. ${ }^{206}$ Having received the proposal and agreed to act as nominee, ${ }^{207}$ the official receiver is then required to send to the creditors (and any private sector trustee in bankruptcy who is in office) a notice containing prescribed information inviting creditors to approve or reject the proposal. ${ }^{208}$ In contrast with the usual IVA procedure outlined in Section B, there is no requirement for a creditors' meeting and the creditors simply vote in favour or against the proposal on the form provided and return it to the official receiver within a prescribed period. $^{209}$ There is no scope for creditors to seek modifications of the proposal: it is put to them on a "take it or leave it" basis. ${ }^{210}$ The proposal is approved if a majority in excess of three-quarters in value of the creditors who vote are in favour of it. ${ }^{211}$ The official receiver is obliged to report to the court whether the proposed IVA has been approved or rejected and, if approved, it will take effect and bind all creditors at

\footnotetext{
${ }^{204}$ Section E1, supra. There is, of course, nothing to stop the credit reference agencies recording the information in their own databases before it is expunged from the individual insolvency register.

${ }^{205}$ IA, s 263A. IR, r 5.37(1)(a) contemplates that the official receiver may charge a fee for acting as nominee, presumably to cover the costs of assisting the debtor in preparing the proposal.

${ }^{206}$ IA, s 263B(1); IR, r 5.37.

${ }^{207} \mathrm{IA}, \mathrm{s} 263 \mathrm{~B}(1)$; IR, r 5.38 .

${ }^{208}$ IA, s 263B(2), (4); IR, r 5.39.

${ }^{209} \mathrm{IR}, \operatorname{rr} 5.39(2), 5.40$.

${ }^{210}$ IA, s 263B(4)(c); IR, r 5.39(1)(b)(iii).

${ }^{211}$ IR, r 5.43.
} 
that time, ${ }^{212}$ subject only to possible revocation by the court on grounds of unfair prejudice or material irregularity. ${ }^{213}$ Once the time has expired for the IVA to be challenged on those grounds, the official receiver will apply to have the bankruptcy order annulled. ${ }^{214}$ The procedure is therefore designed to provide a streamlined exit route out of bankruptcy.

The provision of a more streamlined means of channelling debtors out of bankruptcy into post-bankruptcy IVAs is designed (along with the reforms to IPOs) to advance the policy that debtors who have the ability to pay should make a meaningful contribution towards payment of their debts. ${ }^{215}$ By allowing the official receiver to act as nominee and supervisor of post-bankruptcy IVAs, the legislation is also designed to promote competition between the official receiver and the private sector and so stimulate the hitherto moribund market for post-bankruptcy IVAs. ${ }^{216}$ The key ingredient is costs. In theory, the official receiver should be able to generate economies of scale and keep costs low. The fact that no creditors' meeting is required and that the proposal is made on a "take it or leave it" basis means that the front-end costs of setting up an IVA can be kept to a minimum. The likely standardisation of proposals should also contribute to further cost reductions over time. The inspiration for the reform derives from the debtor payment plan model in Chapter 13 of the US Bankruptcy Code, ${ }^{217}$ although it is no slavish imitation. In Chapter 13 , the debtor gets to keep his assets but must make contributions from income over time (usually three years) under a court-approved payment plan. This perhaps gives us some clue as to how the incentives under sections $263 \mathrm{~A}-\mathrm{G}$ are intended to operate. The theoretical enticements for the bankrupt are (i) the annulment of the bankruptcy and

\footnotetext{
${ }^{212} \mathrm{IA}, \mathrm{s} 263 \mathrm{D}(1),(2)$.

${ }^{213}$ IA, s 263F: IR, r 5.46.

${ }^{214}$ IA, s 263D(3), (4); IR, rr 5.57-9.

${ }^{215}$ Fresh Start, para 7.9.

${ }^{216}$ Fresh Start, para 7.13; Second Chance, para 1.44. The market for IVAs was previously widened by IA, s 389A (inserted by Insolvency Act 2000, s 4) to allow members of recognised bodies as well as insolvency practitioners to act as nominees or supervisors. There is scope for further widening as IA, $\mathrm{s}$ 389B(2) empowers the Secretary of State to extend the official receiver's authorisation by statutory instrument so that he could act in relation to any IVA, whether pre- or post-bankruptcy. It may be doubted whether the Enterprise Act reforms create a level playing field. Although, it is true to say that the official receiver presently has no experience of establishing and supervising IVAs, the "fast track" procedure, together with its associated costs advantages, cannot be used by nominees from the private sector. However, under Enterprise Act 2002, s 264(2)-(4), the Secretary of State has the power to extend the "fast track" procedure beyond its current confines and so make it available for use in the future by the private sector as well as the official receiver.

${ }^{217}$ Fresh Start, para 7.13-14. On Chapter 13 see Tabb, supra n 32, ch 12 and "The Death of Consumer Bankruptcy in the United States?" (2001) 18 Bankruptcy Developments Journal 1.
} 
(presumably) (ii) the prospect of entering into a "payment plan" style of arrangement under which he may get to keep most, if not all, of his assets. The creditors (so it is claimed) can be expected to agree to such "payment plan" IVAs because (i) in most bankruptcy cases there are no or few assets and (ii) in any event, the reduced costs of IVAs are likely to produce better returns even where the creditors agree to forego their claim to any assets that would be available in bankruptcy. ${ }^{218}$ As conceived, the "fast track" post-bankruptcy IVA is therefore a low-cost payment plan model that seeks to offer sufficient benefits to both debtors and creditors to make it viable.

It is questionable whether this procedure will produce the desired results given the overall structure of debtor incentives under the new law. Even if "fast track" IVAs are better for creditors than bankruptcy because less of the income contributed is absorbed in costs, there are no particularly compelling legal incentives for bankrupts to favour IVAs over bankruptcy. Bankrupts with no or few assets - and we are told that these are the majority ${ }^{219}$ — have nothing obvious to lose by staying in bankruptcy. The incentive to opt for an IVA so as to preserve assets simply does not operate. Apart from cost differentials (which benefit creditors rather than debtors) there is no obvious difference between a "no assets" bankruptcy in which the debtor agrees to a three-year IPA ${ }^{220}$ and a three-year "payment plan" IVA. Indeed, the benefit of early discharge, the risk that the debtor may default on the terms of the IVA and end up in bankruptcy anyway and the reduction in the stigma attaching to bankruptcy per se may provide considerable incentives for remaining bankrupt. This is a fortiori if (i) creditors demand IVAs that are longer in duration than three years and (ii) there is no particular advantage in terms of reacquisition of credit between IVA and bankruptcy. ${ }^{221}$ It is true that in bankruptcy the debtor runs the risk of being subjected to post-discharge restrictions. However, this risk is not entirely removed if the debtor exits from bankruptcy into an IVA $^{222}$ and, in any event, if BROs and BRUs are narrowly targeted, not least because of their resource implications, ${ }^{223}$ the risk may be one that is worth running. Those debtors with significant assets or good reasons to avoid the remaining restrictions on undischarged bankruptcies, such as members of

\footnotetext{
${ }^{218}$ Fresh Start, paras 7.10, 7.13. On the point that most bankrupts tend to have no assets see also Pond, supra $\mathrm{n} 96$.

${ }^{219}$ Supra, n 218.

${ }^{220}$ Section C4, supra.

${ }^{221}$ See Pond, supra n 96 suggesting that credit providers equate IVAs with bankruptcy.

${ }^{222}$ Section E7, supra.

${ }^{223}$ Section E8, supra.
} 
professions, can be expected to propose pre-bankruptcy IVAs. ${ }^{224}$ Thus, given the overall incentives, the flourishing of "fast track" IVAs appears to depend heavily on the persuasive powers of the official receiver and the human motivation of individual debtors. ${ }^{225}$

\section{G. CONCLUSION}

At the heart of the reforms lies a complex attempt to differentiate "honest" from "culpable" bankrupts based on a policy platform that is concerned with the removal of legal barriers to enterprise and entrepreneurship. On the assumption that only a small minority of bankrupts will end up subject to BROs or BRUs, ${ }^{226}$ bankruptcy for the majority looks set to become significantly more liberal in the light of the shorter period before discharge and the reduced scope of pre-discharge bankruptcy restrictions. The disassociation of the "honest" from the "culpable" is achieved principally through the post-discharge restriction regime and is intended to encourage credit providers to liberalise their policies in relation to bankrupts who do not fall foul of it so as to improve the prospects for reacquisition of credit. However, the investment that the new regime requires will only be worth the candle if lenders respond positively to the information it produces. The government has conceded that most bankrupts have no or few assets, ${ }^{227}$ hence the emphasis on capturing income through IPOs/IPAs or "fast track" IVAs. This being so, it appears that in the majority of cases, many of which may involve consumer rather than business debtors, the reforms will strengthen the incentives for debtors to shed debt through bankruptcy rather than seeking rehabilitation through an IVA. It therefore seems credible that the

\footnotetext{
${ }^{224}$ For an existing mechanism designed to encourage the use of IVAs in small voluntary bankruptcies see IA, ss 273-4. This enables the court to adjourn a debtor's bankruptcy petition and appoint an insolvency practitioner to consider the viability of an IVA. It is not known whether the provisions are widely used in practice.

${ }^{225}$ It would clearly be wrong to assume that all debtors will act in the rational calculating way predicted by certain strands of economic theory. Some may be ashamed of the failure to pay their debts and more concerned to repay as much as they can through an IVA so as to salvage their pride. The attitudes of those who provide access points into the system such as lawyers, insolvency practitioners and debt advisers may also be influential.

${ }^{226}$ The figures for directors' disqualifications can be used to produce a crude measure. Currently, disqualifications are running at a rate of roughly 1,500 per annum (source: DTI, Companies in 20032004). If we assume that the rate of bankruptcy remains constant at around 25,000 per annum and BROs or BRUs are obtained at the current rate of disqualifications, then significantly less than $10 \%$ of bankrupts will end up subject to post-discharge restrictions.

${ }^{227}$ Supra, n 218
} 
increasing rate of bankruptcies experienced in the last quarter of 2003 and during $2004^{228}$ will be sustained or will rise still further. Moreover, subject to possible concerns about credit-rating, especially in the mortgage market, the claim that the main beneficiary of the reforms may turn out to be consumer rather than business bankrupts also appears credible. Given that the post-discharge restrictions regime and the official receiver's new role in relation to IVAs already place additional burdens on the Insolvency Service, it also seems likely that any increase in the incidence of bankruptcy could put considerable pressure on the system. If these fears prove to be accurate - and, in particular, if there is further expansion in the numbers of consumer bankruptcies - there is every likelihood that the current policy will have to be revisited sooner rather than later. Thus, in time, the Enterprise Act reforms may prove to have been something of a high water mark in the history of English insolvency law. ${ }^{229}$

\footnotetext{
${ }^{228}$ Supra, n 99.

${ }^{229}$ Experience in the United States, where bankruptcy filings increased roughly fourfold between 1980 and 2000, while not directly comparable, may be instructive. There Congress has sought to means-test access to Chapter 7 bankruptcy. Consumer debtors whose net monthly income exceeds a defined threshold would be denied access to Chapter 7 and effectively be forced to consider the option of a Chapter 13 income payment plan were the proposal to be enacted. For background and critique see Ziegel, supra n 31; Tabb, supra n 217.
} 